\title{
Mechanism of drug-induced liver injury and hepatoprotective effects of natural drugs
}

\author{
Yongfeng Zhou ${ }^{1,3+}$, Junnan Wang ${ }^{2,3 \dagger}$, Dingkun Zhang ${ }^{1 \dagger}$, Jiaxin Liu ${ }^{3}$, Qinghua Wu' ${ }^{1}$ Jiang Chen ${ }^{1}$, Peng Tan ${ }^{1}$,
} Boyu Xing ${ }^{3}$, Yanzhong Han ${ }^{1,3}$, Ping Zhang ${ }^{3^{*}}$, Xiaohe Xiao ${ }^{4^{*}}$ and Jin Pei ${ }^{1^{*}}$

\begin{abstract}
Drug-induced liver injury (DILI) is a common adverse drug reaction (ADR) and a serious threat to health that affects disease treatments. At present, no targeted clinical drugs are available for DILI. Traditional natural medicines have been widely used as health products. Some natural medicines exert specific hepatoprotective effects, with few side effects and significant clinical efficacy. Thus, natural medicines may be a promising direction for DILI treatment. In this review, we summarize the current knowledge, common drugs and mechanisms of DILI, as well as the clinical trials of natural drugs and their bioactive components in anticipation of the future development of potential hepatoprotective drugs.
\end{abstract}

Keywords: Natural medicines, Drug-induced liver injury, Bioactive components, Mechanism

\section{Introduction}

Drug-induced liver injury (DILI) is an adverse drug reaction (ADR) that occurs in clinical applications. With the aggravation of the disease, DILI may progress to liver fibrosis, liver failure and even death and is a serious health threat $[1,2]$. According to incomplete statistics, more than 1000 drugs may cause different degrees of liver injury [3]. In Western countries, the incidence of DILI is estimated to be (1-20)/100,000 of the total population [4-7]. The incidence of DILI in the state of Delaware, United States, is $2.7 / 100,000$ [8]. In China, the annual incidence in the general population is $23.80 / 100,000$, which is higher than that reported in Western countries.

\footnotetext{
*Correspondence: zhp1231@126.com; pharmacy302xxh@126.com; peixjin@163.com

†Yongfeng Zhou, Junnan Wang and Dingkun Zhang contributed equally to this work

${ }^{1}$ College of Pharmacy, Chengdu University of Traditional Chinese Medicine, 1166 Liutai Avenue, Wenjiang District, Chengdu 611137, Sichuan, China

${ }^{3}$ Department of Pharmacy, Medical Supplies Center of PLA General Hospital, 100\#, West 4th Ring Middle Rd., Fengtai, Beijing 10039, China

${ }^{4}$ Department of Liver Disease, Fifth Medical Center of PLA General Hospital, 100\#, West 4th Ring Middle Rd., Fengtai, Beijing 10039, China Full list of author information is available at the end of the article
}

Traditional Chinese medicine and dietary supplements (26.81\%) and anti-tuberculosis drugs (21.99\%) are the two main categories of drugs causing DILI [9].

Some commonly used clinical drugs for DILI treatment include tiopronin, polyene phosphatidylcholine, ursodeoxycholic acid and $\mathrm{N}$-acetylcysteine [10]. However, because the mechanism underlying the development of DILI is multisourced and complex, specific drugs for its treatment are still lacking.

Natural medicine is a treasure from nature to humans. Some natural drugs exert significant hepatoprotective effects on individuals with DILI. The concept of 'natural therapy' has been proposed in recent years, causing more people to pay attention to natural drugs. Most natural drugs have some problems, such as unclear compositions or unclear mechanisms of action, which seriously hinder their clinical applications and the development of new drugs.

In this paper, we performed a literature search using mainly Web of Science, PubMed, Google Scholar, CNKI, and VIP. We summarize the common types of drugs that cause DILI, the causes of liver injury, the mechanism of liver protection, the material basis of natural drugs and original author(s) and the source, provide a link to the Creative Commons licence, and indicate if changes were made. The images or other third party material in this article are included in the article's Creative Commons licence, unless indicated otherwise in a credit line to the material. If material is not included in the article's Creative Commons licence and your intended use is not permitted by statutory regulation or exceeds the permitted use, you will need to obtain permission directly from the copyright holder. To view a copy of this licence, visit http://creativecommons.org/licenses/by/4.0/. The Creative Commons Public Domain Dedication waiver (http://creativeco mmons.org/publicdomain/zero/1.0/) applies to the data made available in this article, unless otherwise stated in a credit line to the data. 
the clinical application of related drugs to provide a scientific basis and corresponding countermeasures for the development of potential hepatoprotective drugs based on natural medicine.

\section{Common drugs and mechanism of DILI Anti-TB drugs}

Antituberculosis DILI (ATDILI) is a common form of DILI that often leads to the interruption of tuberculosis treatment and hinders the treatment process. At present, widely used anti-tuberculosis drugs in clinical applications with significant effects are mainly isoniazid (INH), rifampicin (RFP), aminosalicylic acid and levofloxacin, which can lead to DILI. As the applied doses of these drugs increase, their adverse reactions become more obvious [11]. Some factors, including female, drinking alcohol, liver disease, systemic lupus erythematosus or malnutrition, also increase the probability of liver damage caused by antituberculosis drugs $[12,13]$. In recent years, researchers have found that CYP450, UGT, GST, NAT and other drug-metabolizing enzymes, as well as $\mathrm{ABCB} 1, \mathrm{ABCC} 2$ and other drug transporters and human leukocyte antigen gene polymorphisms, are positively correlated with the incidence of ATDILI [14, 15]. Furthermore, a polymorphism in the cytochrome P450 oxidoreductase gene, rs3898649, is significantly associated with ATDILI susceptibility, suggesting that it may be a potential biomarker involved in ATDILI [16] and could be helpful in the clinical diagnosis of ATDILI.

At present, the occurrence of ATDILI is presumed to mainly involve immune mechanisms and nonimmune mechanisms [17]. The immune mechanism is based on the increase in the histamine content in the body and induction of type I allergies by antituberculosis drugs. They can also use haptens to form an immune complex that causes type II, III and IV allergies and subsequent liver injury. The immune response recruits inflammatory cells that continuously release cytokines to act on hepatic sinusoidal cells, resulting in local circulatory disorders. Inflammatory response-induced stress kills hepatocytes. This process has no relation with the dosage. Low doses of rifampicin, isoniazid and pyrazinamide cause immune-mediated liver injury [18]. The nonimmune mechanism mainly involves the metabolic reaction of anti-TB drugs in vivo. Two main types of metabolic damage have been identified: direct and indirect damage to hepatocytes. However, both types have an obvious dose-response relationship with the drug dose, such as isoniazid, aminothiourea, rifampicin, ethylthioisoniazid, pyrazinamide and isonicotinamide. Direct hepatotoxicity of drugs and their metabolites includes the deformation and necrosis of hepatocytes. In addition, metabolites and drugs inhibit or block the metabolic function of hepatocytes or bile excretion function to subsequently damage hepatocytes or disrupt bile excretion, resulting in liver injury [19] (Fig. 1).

\section{Antitumour drugs}

Antitumor drugs exert a therapeutic effect by inhibiting or killing tumor cells in the body. Thus, they inevitably damage normal cells, tissues and organs, which may lead to many adverse reactions, including DILI and kidney injury. Liver injury caused by these drugs usually occurs 1-2 weeks after medication and may result in pathological symptoms, such as hepatocyte necrosis, cholestasis and mixed liver injury. The combination of multiple antitumor drugs increases the incidence of liver injury [20]. At present, research on platinum antitumor drugs is relatively extensive. According to reports, oral antitumor drugs are the main mode of administration, accounting for $30-50 \%$ of all antitumor therapies. Oral administration improves the safety of tumor treatment, but in some cases, the administration of an improper causes adverse effects [21]. The appropriate adjustment of the drug dosage based on hepatotoxicity examinations might effectively prevent liver damage caused by antitumor drugs [22].

Cisplatin (CP) is the first platinum antitumor drug approved by the U.S. Food and Drug Administration (FDA). It has a wide antibacterial spectrum, strong antitumor effect and antitumor activity greater than $60 \%$. It is a first-line chemotherapeutic drug [23]. However, CP significantly reduces immune function and causes liver injury while resisting tumor cells [24]. CP is metabolized in the liver, and its accumulation in the liver is second only to that in the kidney. Its injury is mainly caused by inducing oxidative stress, apoptosis and inflammatory injury in the liver. Reactive oxygen species (ROS) accumulation following CP-induced ROS production or abnormal expression of cytochrome $\mathrm{P} 450$ 2E1 (CYP2E1) results in oxidative stress and injury in the liver [25].

\section{Nonsteroidal anti-inflammatory drugs}

Nonsteroidal anti-inflammatory drugs (NSAIDs) have good clinical analgesic and antipyretic effects. However, liver injuries lead to cancellation or withdrawal from the market during the premarket or postmarket evaluation stage. Seven types of NSAIDs cause severe DILI, including diclofenac, ibuprofen, sulindac, aspirin, naproxen, piroxicam and nimesulide. These drugs account for $99 \%$ of all NSAIDs [26].

Diclofenac is an NSAID that causes rare but severe liver toxicity through an unclear mechanism. Some studies have explored the role of the immune response in the 


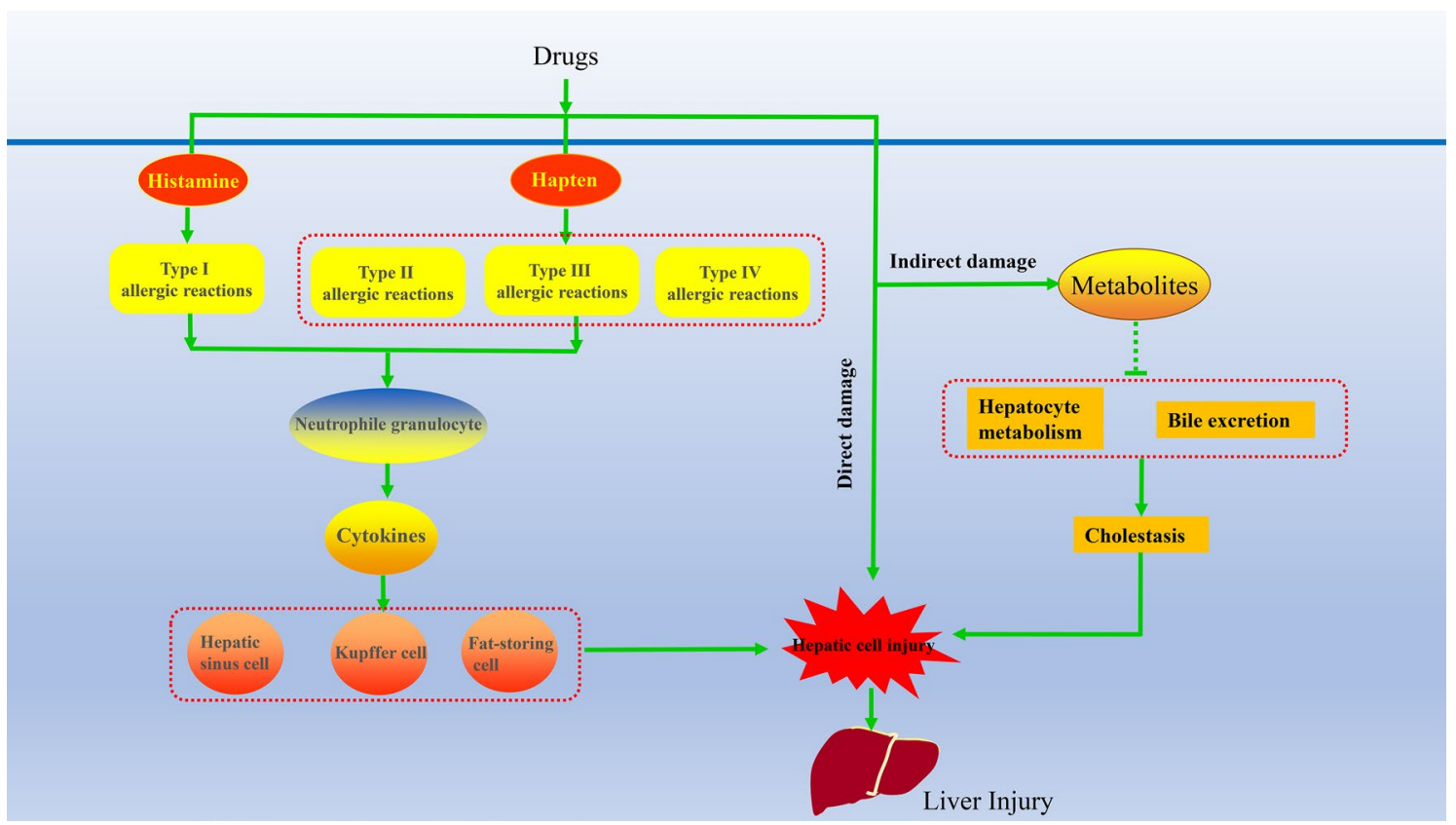

Fig. 1 Possible mechanism of Anti-TB drugs (example as INH). Drugs can make hepatic cells continuously release inflammatory cytokines and response-induced stress kills hepatocytes. Direct hepatotoxicity of drugs and their metabolites includes the deformation and necrosis of hepatocytes

process of liver injury. By determining the genetic polymorphisms in patients, researchers found that low levels of IL-10 and high levels of IL-4 gene transcription contribute to Th-2-mediated antibody binding to new antigens related to disease susceptibility [27].

Acetaminophen (APAP) is an NSAID with definite hepatotoxicity in clinical applications. At present, the main cause of APAP-induced hepatotoxicity is its metabolite $\mathrm{N}$-acetyl-p-benzoquinone imine (NAPQI). APAP is mainly metabolized into glucosinolates and sulfates. When treated with APAP, these compounds accounted for $80-90 \%$ of the total metabolites. A small amount of APAP is metabolized by CYP450 to produce an intermediate, and the intermediate generates NAPQI. NAPQI directly interacts with glutathione, which exerts a detoxification effect. When glutathione is depleted, hepatocytes are affected by toxic metabolites, causing cell necrosis [28-30]. APAP toxicity is mediated by nitric oxide (NO), which scavenges superoxide and produces peroxynitrite, resulting in protein nitration (3-tyrosine) and tissue damage [31, 32] (Fig. 2).

\section{Anti-epileptic drugs (AEDs)}

The treatment of epilepsy requires the long-term use of anti-epileptic drugs. ADR may occur in this process, affecting the treatment and quality of life of patients and, in severe cases, even threatening their life. Carbamazepine, phenobarbital, valproic acid, phenytoin, lamotrigine, and felbamate are associated with DILI [33]. Recent studies have shown that liver injury caused by carbamazepine may be related to drug metabolism and mitochondrial dysfunction [34].

Under the action of the CYP450 enzyme, the metabolites of AEDs covalently bind to the macromolecular proteins in cells or directly peroxidate the unsaturated fatty acids on the hepatocyte membrane, resulting in reduced ATP levels. The dynamic imbalance of $\mathrm{Ca} 2+$ in the cells leads to the rupture of actin fibers near the hepatocyte surface and disruption of the vesicular structure of the cell membrane, and then the cells rupture and dissolve [35].

Another mechanism of AEDs is blocking the beta oxidation and respiratory chain functions of mitochondria, leading to the failure of normal metabolism of free fatty acids, increased anaerobic fermentation, the accumulation of lactic acid and mitochondrial ROS production. ROS oxidize liposomes, cause lipid peroxidation, alter the mitochondrial membrane permeability, induce mitochondrial DNA damage, and induce cytokine (such as TNF- $\alpha$ and IL-8) production, further promoting liver damage [36]. 


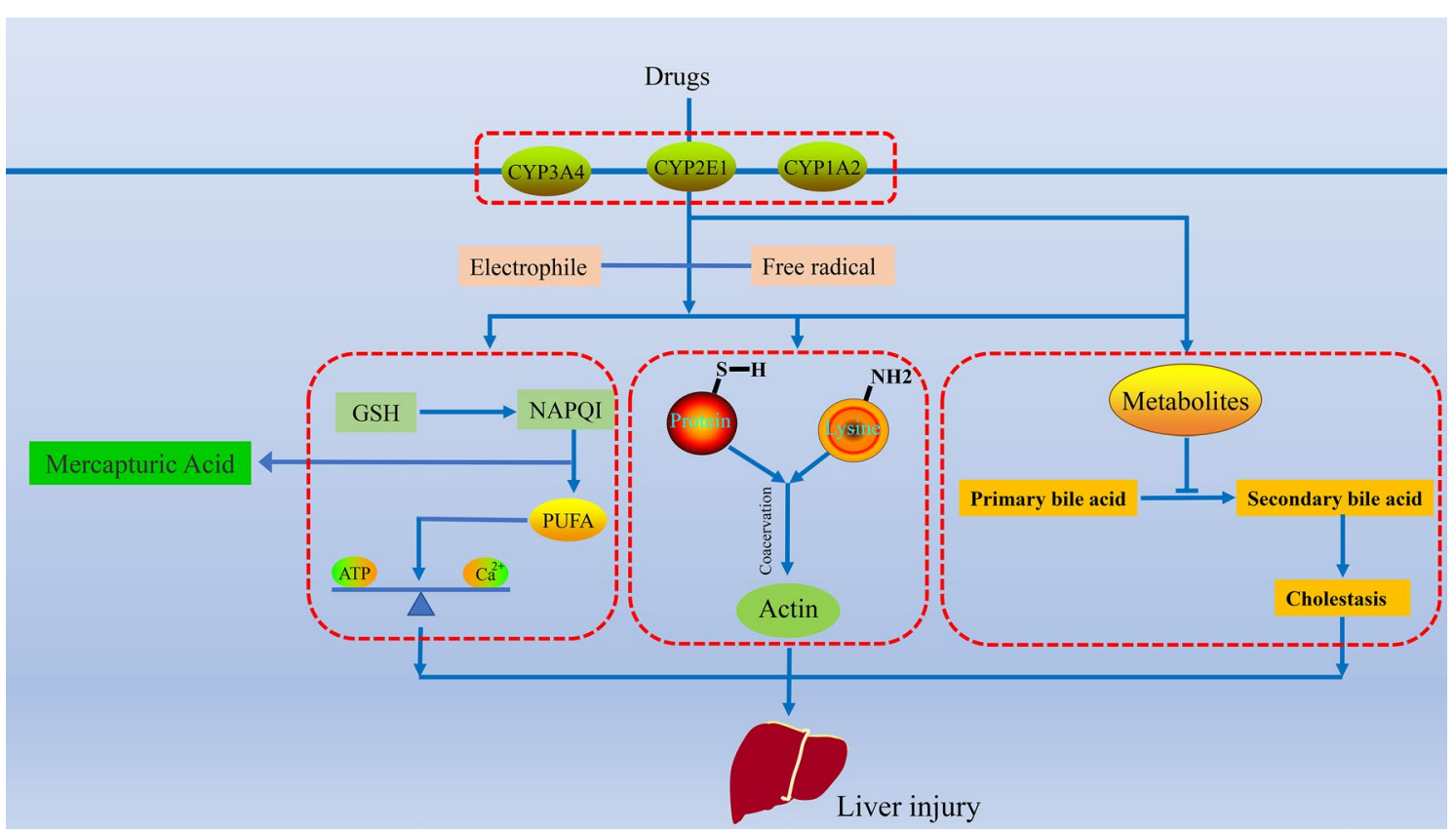

Fig. 2 Possible mechanism of NSAIDs (example as APAP). The potential mechanisms involved are CYP450 metabolites interact with cellular macromolecules, destroy protein structure, lipid peroxidation, destroy ion gradient, and disrupt calcium ion transport, inhibit ATP synthesis and bile acid synthesis

\section{Anti-fungal drugs}

Ketoconazole $(\mathrm{KT})$ is a typical antifungal drug, but its hepatotoxicity mechanism has not been resolved. Children and people over 60 years of age who take KT have liver toxicity incidences of $2.2 \%$ and $14 \%$, respectively. In addition, people who take KT orally have a higher incidence $(5.5 \%)$ of liver toxicity than specified in the drug instructions [37]. Some scholars have suggested that active metabolites may be the cause of liver toxicity. One reported metabolite of $\mathrm{KT}$ is $\mathrm{N}$-deacetyl ketoconazole (DAK). DAK is further metabolized by flavin-containing monooxygenases (FMOs) into the potentially toxic molecule dialdehyde [38].

\section{Chinese herbal medicine}

In recent years, the side effects of hepatotoxicity caused by Chinese herbal medicine have become increasingly prominent due to the increased use of Chinese medicine and have even become one of the main causes of DILI. According to reports, herb-induced liver injury (HILI) accounts for approximately 23.61\% (34/144 cases) of all DILI cases [39]. A literature review found that the main Chinese herbal medicines that cause HILI include Polygonum multiflorum, Psoralen, Corydalis and Rhubarb [40], in which alkaloids and terpenoids are the main causes of hepatotoxicity [41]. The main reasons for the increase in HILI include the unqualified quality of traditional Chinese medicine, nonstandard clinical use, long-term treatment with large doses and improper compatibility, which lead to the aggravation of its toxic side effects [39]. HILI is not exclusively caused by Chinese herbal medicine itself. Rather, multidrug combinations, complex compositions, patient physique and other underlying diseases play a role in HILI.

HILI is mainly divided into two types: direct hepatotoxicity and idiosyncratic hepatotoxicity [42]. Direct hepatotoxicity (inherent DILI) is the direct damage caused by drugs and their metabolites to liver cells or mitochondria. It is relatively rare at present and is closely related to drug dosages. It is predictable, controllable and relatively safe [43]. Diosgenin, baicalin, saikosaponin $D$, and tetrandrine reduced the survival rate of L02 cells and increased AST activity. The levels of ALT, LDH and ALP increased in the cell culture medium. The mechanism of liver injury may be related to the activation of $\mathrm{p} 38 \alpha$ [44]. In contrast, idiosyncratic hepatotoxicity (idiopathic DILI) is more common in the clinic and includes immune idiopathic liver injury or inflammatory idiopathic liver injury. This type of DILI has no correlation with the drug dose, is difficult to predict and progresses faster $[45,46]$. One example is liver injury caused by Polygonum multiflorum (PM). 


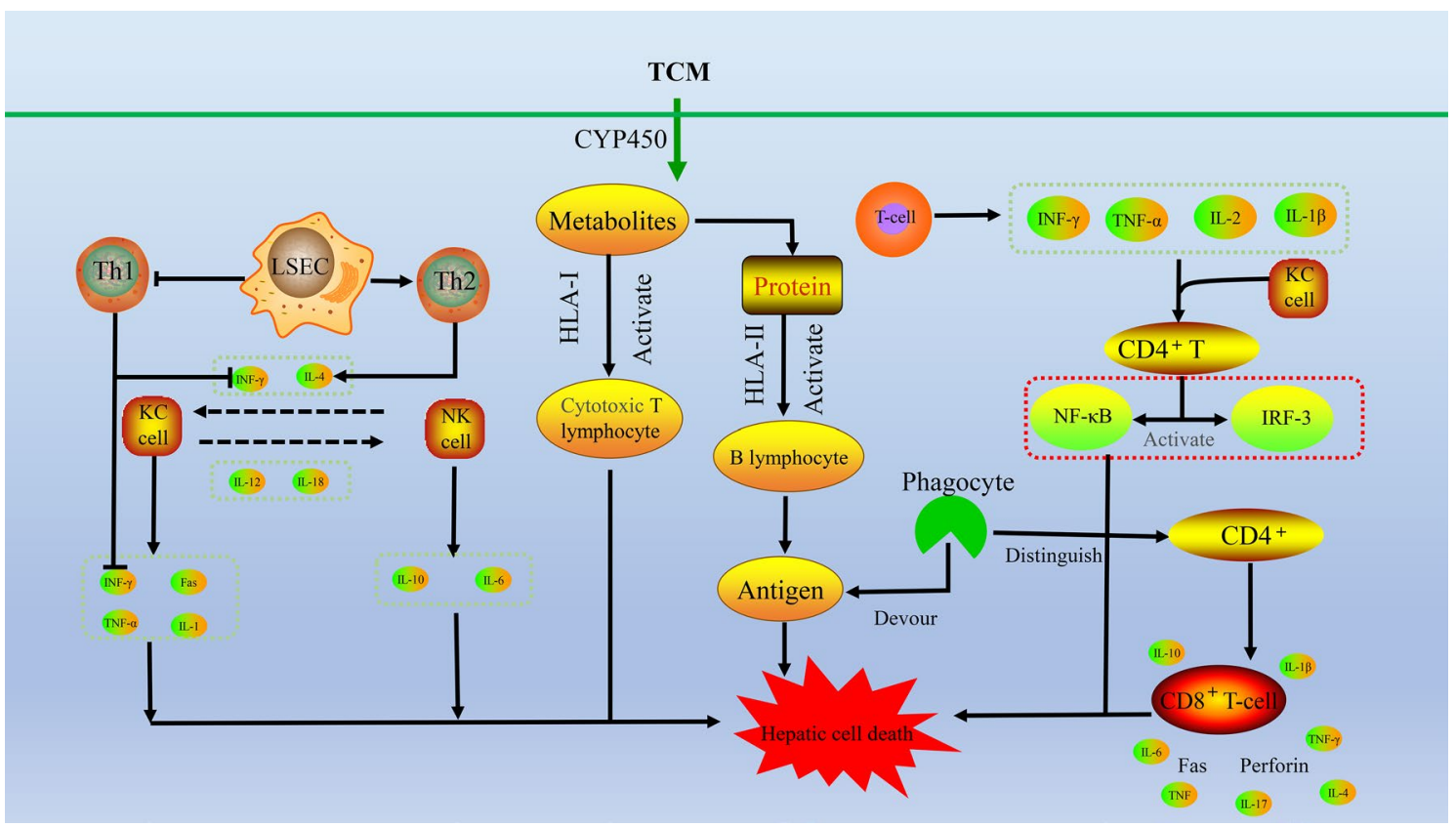

Fig. 3 Possible mechanism of Immune idiosyncratic DILI. Drugs or their metabolic products combine with liver specific proteins to become antigens, which can be phagocytosed by phagocytes and expressed on the cell surface. They can be recognized by CD4 ${ }^{+}$cells, stimulate the production of cytokines, activate the $\mathrm{CD} 8^{+} \mathrm{T}$ cells of effector cells, and produce cytotoxicity leading to liver damage

Cis-stilbene glucoside (cis-SG) is the main component of PM causing DILI. However, the dose of cis-SG leading to liver injury is greater than that used in medicinal materials, indicating that other components of PM may also be involved in inducing liver injury. The main form of stilbene glycoside in PM is trans stilbene glucoside (trans-SG), which exerts an immunomodulatory effect, combined with the key role of immune inflammation in PM-induced liver injury [47]. Idiopathic DILI induced by PM is the result of the synergistic actions of abnormal immune function, immune active components (trans-SG) and potential liver injury-susceptible components (cis-SG) in PM. When the body is in a hyperimmune state, the immune-promoting substances in PM (such as trans-SG) further enhance systemic immunity, increase the sensitivity of the liver to liver injury-susceptible components (such as cis-SG) in PM, and induce IDILI. He et al. [48] used an LPS model to study IDILI and found that compared with trans-SG alone, the liver injury caused by the combination of cisSG and trans-SG at the same dose in medicinal materials was more serious. The same dose of trans-SG only slightly increased the immune response, indicating that trans-SG also played a role in PM-induced heterogeneous liver injury (Fig. 3).

\section{Other}

Chlorpromazine and clozapine are commonly used firstline antipsychotic drugs that cause a certain degree of liver injury. Chlorpromazine directly induces liver toxicity, and clozapine increases the levels of transaminases in patients $[49,50]$. Toxic free radicals are produced from antipsychotic drugs during liver metabolism, which directly inhibit $\mathrm{Na}+-\mathrm{K}+-$ ATP enzyme activities in liver cells, thus reducing the stability of the liver cell membranes and detoxification enzymes and resulting in elevated transaminase levels and chronic liver damage [51].

\section{Bioactive components of natural drugs for liver protection}

A variety of chemical components in natural drugs have certain hepatoprotective activity. According to recent studies, flavonoids, polysaccharides, lignans, alkaloids, terpenes and other components have good hepatoprotective activity and good effects on drug-induced liver injury [52]. Their mechanisms of action are mainly to inhibit lipid peroxidation, promote the recovery of the liver cell membrane, eliminate oxygen free radicals, inhibit mitochondrial dysfunction, ameliorate cholestasis, and inhibit the secretion of inflammatory factors (Fig. 4). 


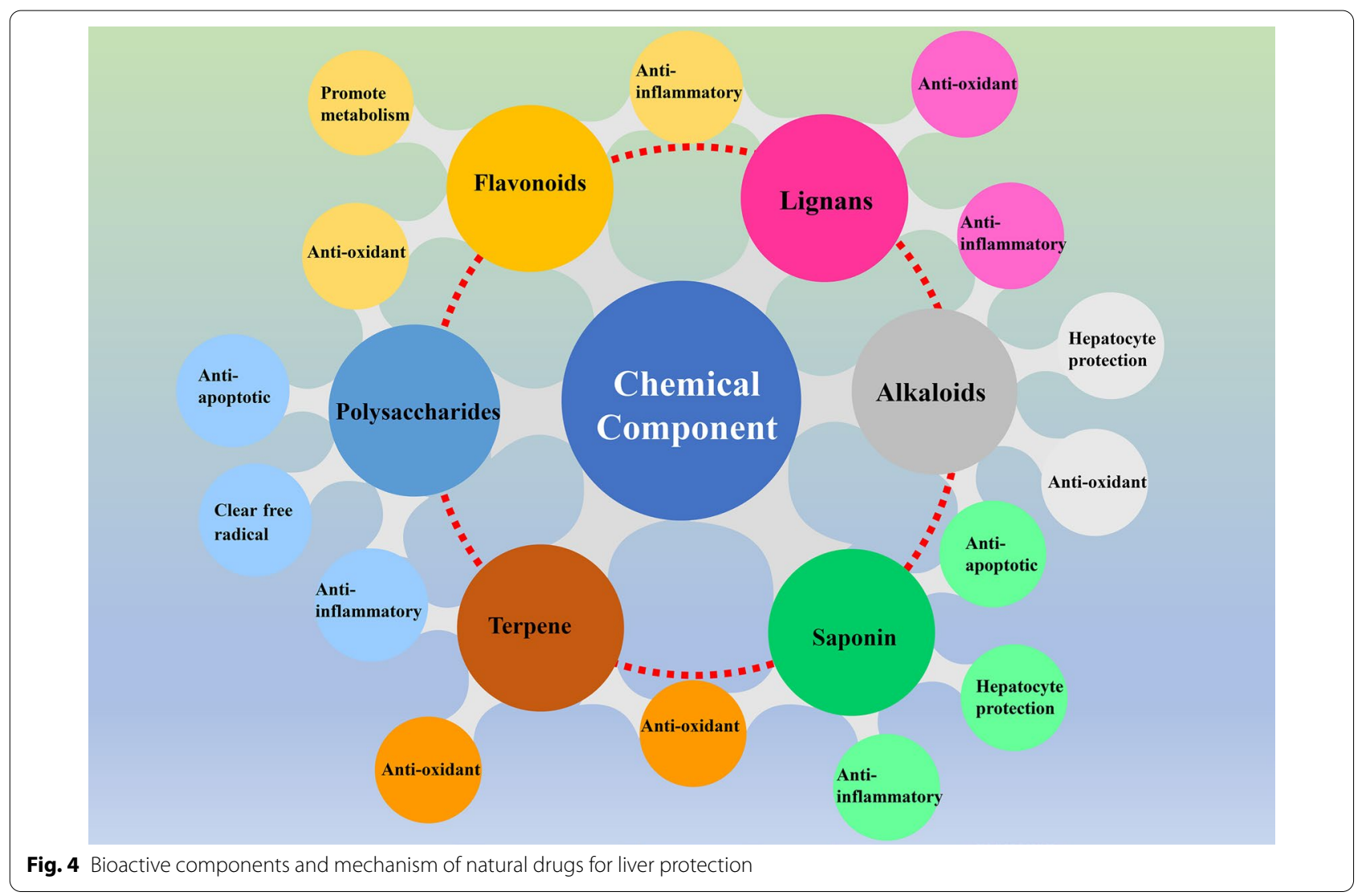

\section{Flavonoids}

Flavonoids are widely distributed in natural drugs and have good activity. They mainly includes flavone, flavonols, dihydroflavonoids and other related compounds. Most flavonoids exert anti-inflammatory, antioxidant and hepatoprotective effects.

\section{Flavone}

Chrysin protects against methotrexate (MTX)-induced hepatotoxicity by restoring cellular antioxidant defenses and downregulating the expression of p53, Bax and caspase 3 [53]. Flavonoids in Rosae Laevigatae Fructus also prevent DNA fragmentation and changes in the mitochondrial ultramicrosome system. The expression of TNF- $\alpha$, Fas/FasL and the Burlington gene was significantly decreased, and the level of Bcl-2 was significantly increased in a previous study [54]. In addition, total flavonoids from Acacia and Propolis also exert protective effects on liver injury [55].

Baicalin protects against liver injury by inhibiting the activity of NF- $\mathrm{KB}$ and reducing TNF production, which may be related to the upregulation of $\mathrm{HO}-1$ protein expression and activity [56].

\section{Flavonol}

Quercetin intervention effectively reduces the APAPinduced liver damage. Its mechanism is not only related to activating the Nrf2 signaling pathway and increasing the activity of antioxidant defenses but also to inhibiting the NF- $\mathrm{kB}$ signaling pathway, which is closely related to reducing the release of proinflammatory factors [57]. Quercetin also inhibits cisplatin-induced liver injury in mice by regulating the NLRP3 inflammasome pathway [58]. Hypericin increases the activity and mRNA expression of uridine diphosphate glucuronosyltransferases (UGTs) and sulfonyltransferases (sults), inhibits CYP2E1 activity, inhibits the formation of toxic intermediates and promotes the detoxification of APAP in the liver [59].

\section{Dihydroflavone}

Hesperidin reduces the infiltration of inflammatory cells and the production of proinflammatory cytokines, blocks the activation of Toll-like receptor (TLR)-4 signaling, and reduces oxidative stress and inflammatory response induced by APAP in mice. Hesperidin inhibits APAP-mediated cytotoxicity, apoptosis and reactive oxygen species (ROS)-induced upregulation of heme oxygenase-1 (HO-1) mRNA and protein expression in mouse AML12 hepatocytes [60]. Naringin significantly 


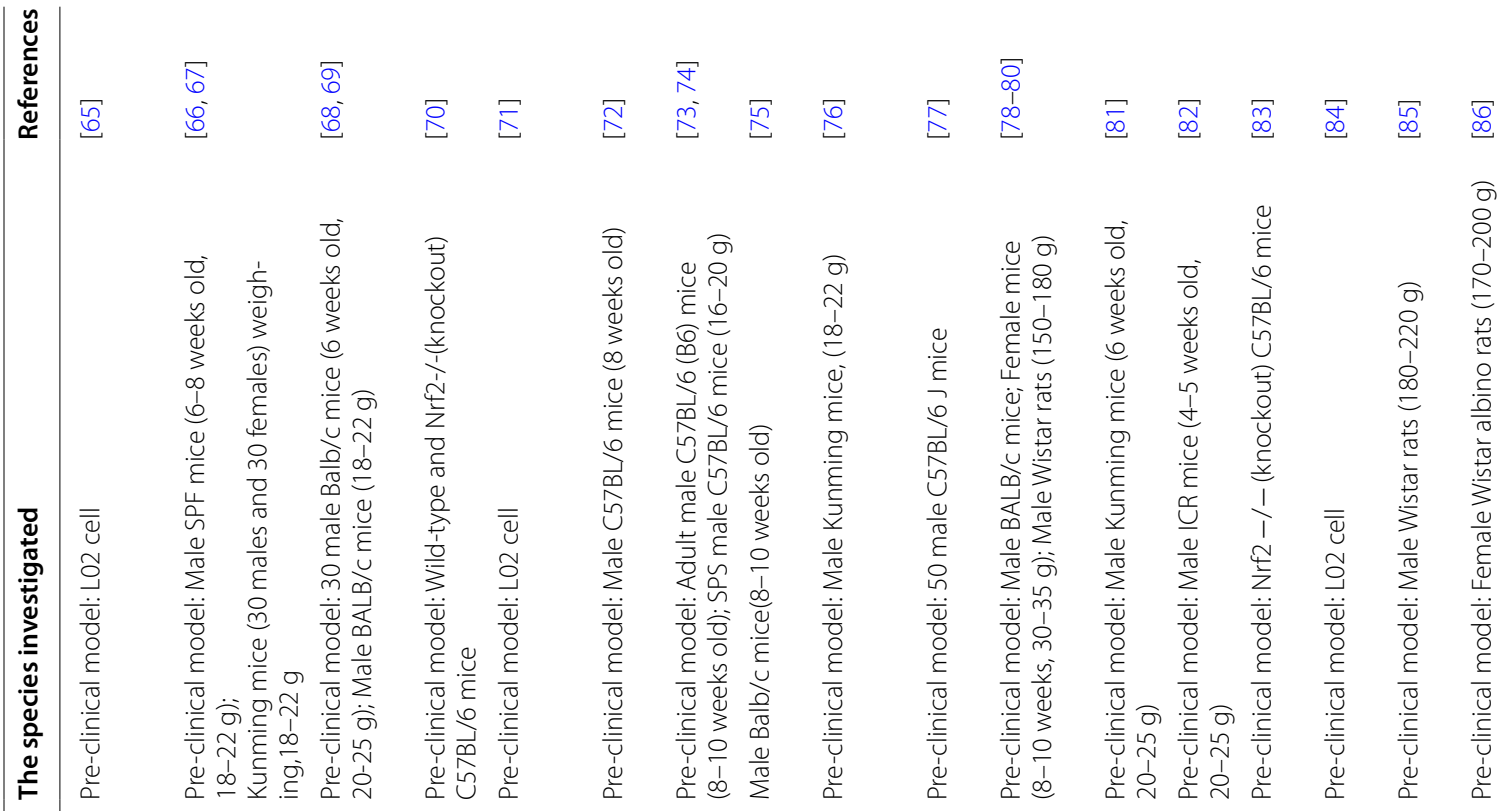

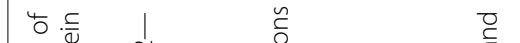

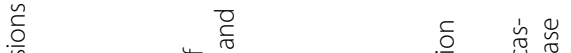

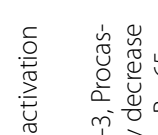

\section{O}

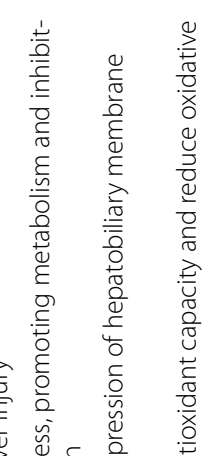

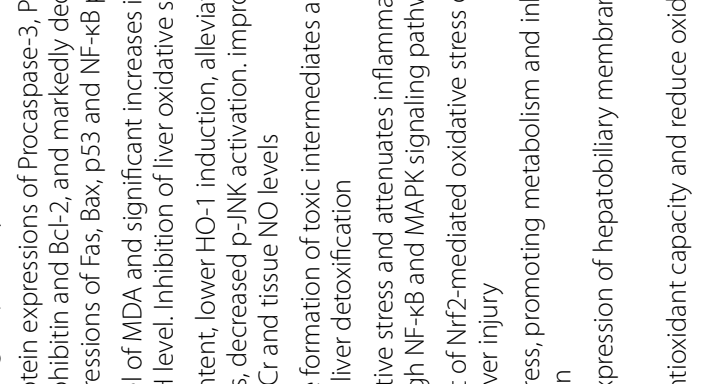

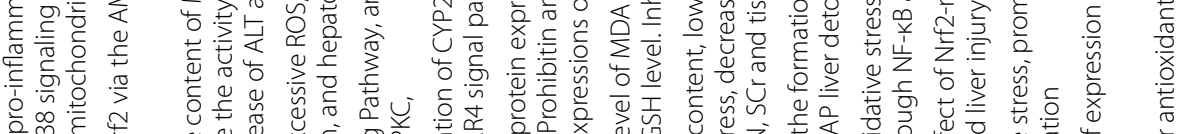

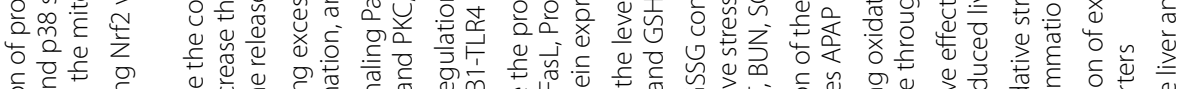

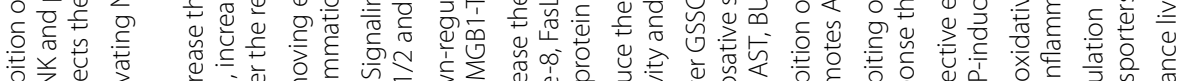

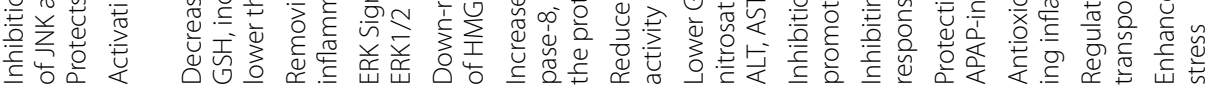

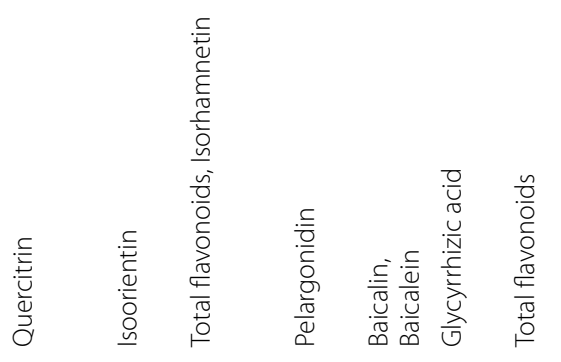

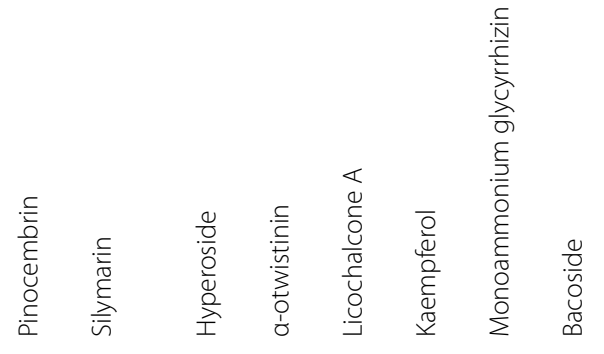




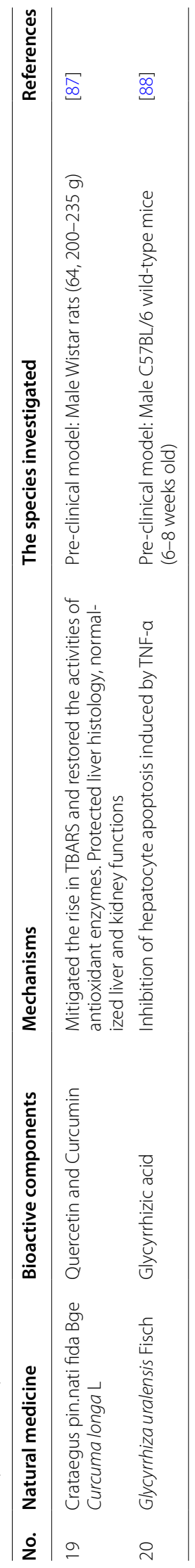


<smiles>COc1c(O)cc2oc3cc(O)c(CC=C(C)C)c(O)c3c(=O)c2c1CC=C(C)C</smiles>

(1)<smiles>O=C1c2c(O)cc(O)cc2O[C@H](c2cc(O)c(O)c(O)c2)[C@@H]1O</smiles>

(2)<smiles>Oc1cc(O)c2c(c1)O[C@H](c1ccc(O)c(O)c1)[C@H](O)C2</smiles>

(3)<smiles>Cc1ccc(C2Oc3cc(O)cc(C)c3CC2CC(=O)c2cc(C)c(O)c(C)c2)cc1C</smiles>

(4)<smiles>COc1cc(OC)c2c(c1)OC(c1cc(OC)c(OC)c(OC)c1)C(CO)C2</smiles>

(5)

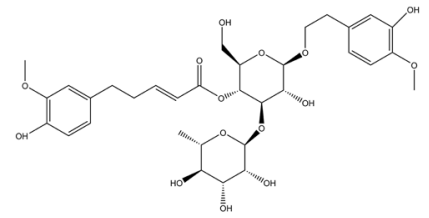

(6)<smiles>Oc1cc(O)c2c(c1)O[C@H](c1ccc(O)c(O)c1)[C@H](O)C2</smiles>

(7)<smiles>C=CC(C)(C)c1cc(/C=C/C(=O)c2ccc(O)cc2)c(O)cc1O</smiles>

(8)

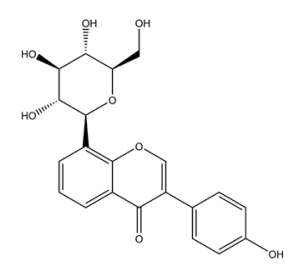

(9)<smiles>Cc1ccc(C2Oc3cc(O)cc(C)c3C(=O)C2O)cc1I</smiles>

(10)<smiles>CC(C)C1CC(C)C(CC2CC3CC(C4CCCCC4)CC(C)C3C(C)C2C)CC1C</smiles>

(11)<smiles>Cc1cc2oc(-c3ccccc3)cc(=O)c2c(Br)c1O</smiles>

(12)<smiles>CC1CC(C)C2C(C1)CC(C1C(C)CC(C)C(C)C1C)C(C1CCC(C)C(C)C1)C2C</smiles>

(13)<smiles>CCCC1CC(CCC(C)CCC(C)CCC2CCC(C)C(CCC)C2)CCC1C</smiles><smiles>CCC1O[C@@H](CC2=C(c3ccc(O)c(O)c3)Cc3cc(O)cc(C)c3C2=O)C[C@@H](O)C1O</smiles>

(15)<smiles>Cc1cc(C)cc(C2Oc3cc(Br)cc(C)c3C[C@@H](C)C2c2cc(C)c(C)c(C)c2)c1</smiles>

(16)<smiles>C=C(CC1Cc2c(C)cc(C)cc2NC1c1cc(C)c(C)c(C)c1)c1cc(C)c(C)c(C)c1</smiles>

(17)<smiles>Cc1cc2c(=O)oc3c(O)c(O)cc4c(=O)oc(c1C)c2c34</smiles>

(18)<smiles>Cc1cc(O)ccc1C1C[C@@H](C)C(=O)c2c(O)cc(O)cc2O1</smiles>

(19)

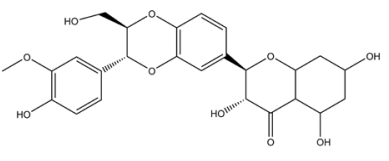

(20)

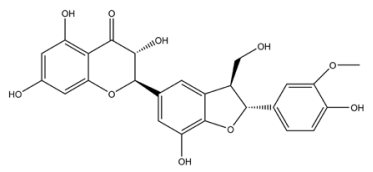

(21)

Fig. 5 The chemical structures of flavonoids showing anti-DILI activity. (1) a-Mangostin; (2) Dihydromyricetin; (3) L-Epicatehin; (4) (-)-Epicatehin gallate; (5) (-)-epigallocatechin; (6) Martynoside; (7) (+)-Catechin; (8) Licochalcone A; (9) Puerarin; (10) Quercetin; (11) Baicalin; (12) Baicalein; (13) Astlbin; (14) Cuecumin; (15) Hyperoside; (16) (-)-Gallocatechin; (17) (-)-Gallocatechin gallate; (18) Ellagic acid; (19) (+)-Taxifolin; (20) Silymarin; (21) Silicristin

increases the IC50 values of troglitazone and diclofenac sodium and reduces the expression of transaminase and caspase3. In addition, naringin prevents DILI by inhibiting the function of the CYP450 enzyme [61]. Josephine exerts an obvious protective effect on APAP-induced liver injury in mice by significantly decreasing the MDA level and significantly increasing SOD activity and the GSH level. Thus, its protective effect may be related to the inhibition of oxidative stress in the liver [62]. 


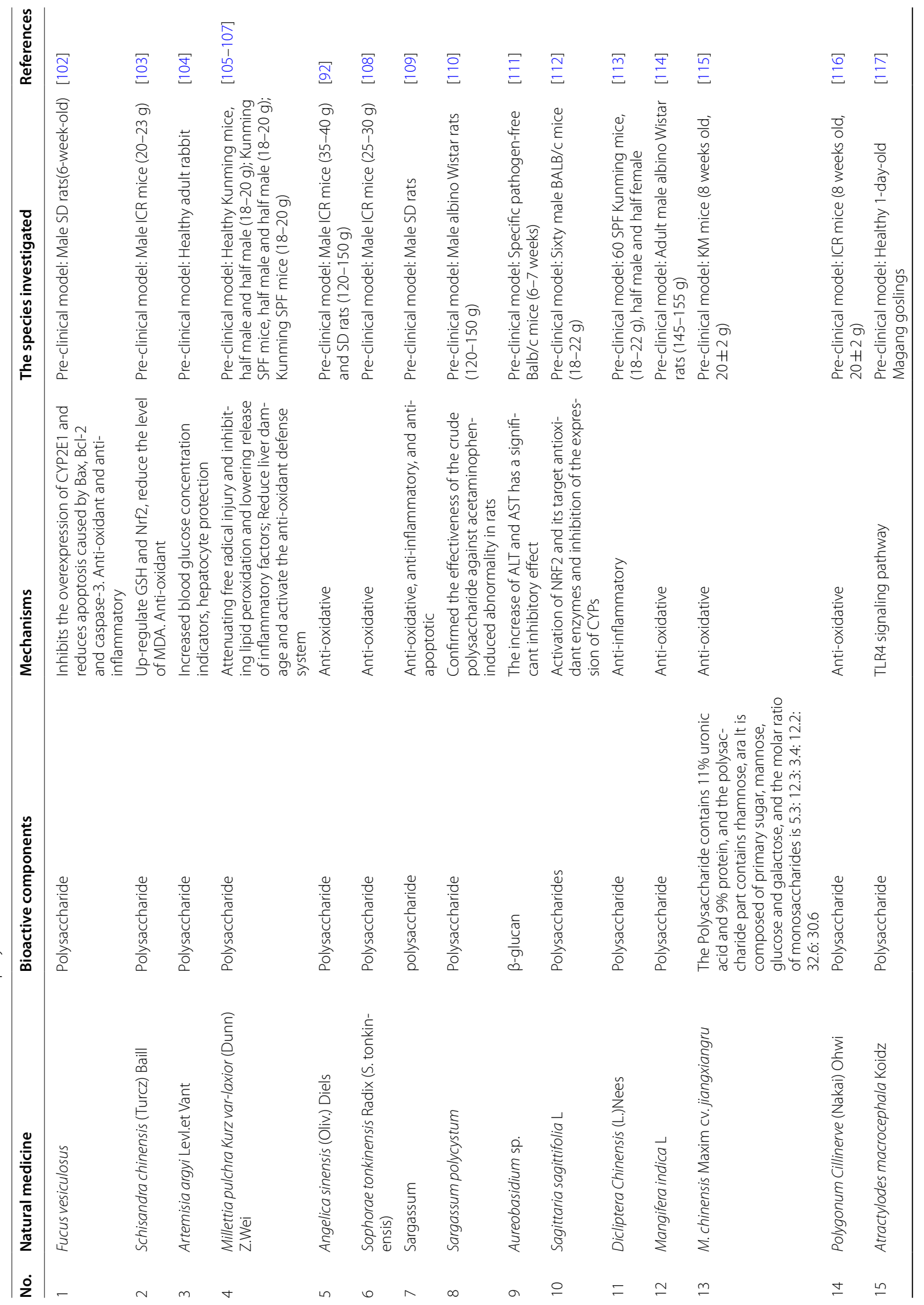




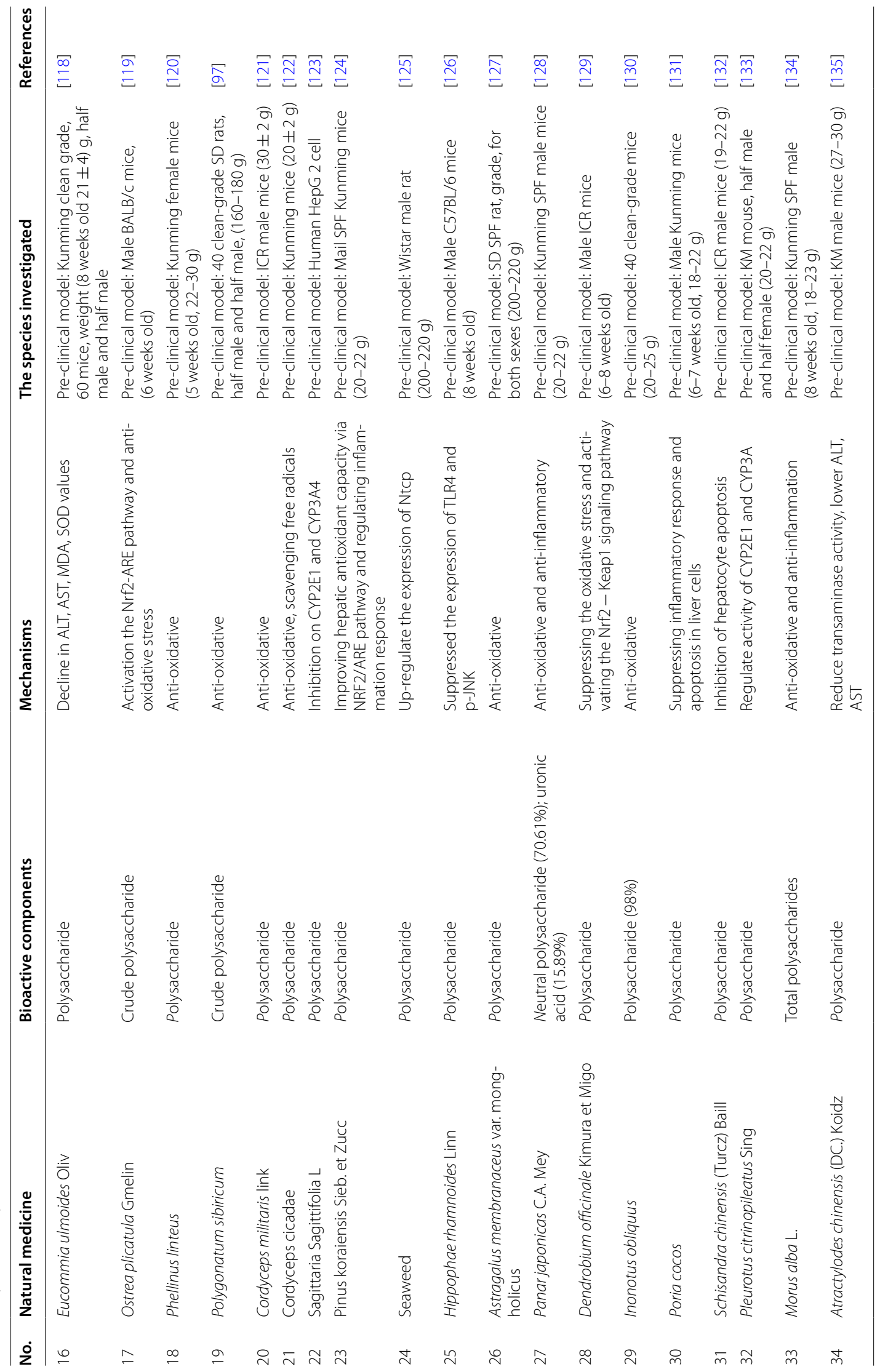


Table 3 Anti-DILI effect and mechanism of Alkaloid in natural medicines

\begin{tabular}{|c|c|c|c|c|c|}
\hline No. & Natural medicine & Bioactive components & Mechanisms & The species investigated & References \\
\hline 1 & Coptis chinensis Franch & Berberine & $\begin{array}{l}\text { Inhibiting oxidative stress, hepato- } \\
\text { cyte necrosis and inflammatory } \\
\text { response }\end{array}$ & $\begin{array}{l}\text { Pre-clinical model: Male C57BL/6 } \\
\text { mice (18-22 g) }\end{array}$ & [136] \\
\hline 2 & Aconitum carmichaelii Debx & Aconine & $\begin{array}{l}\text { Inhibiting mitochondrial dysfunc- } \\
\text { tion }\end{array}$ & Pre-clinical model: HepaRG cells & [137] \\
\hline 3 & $\begin{array}{l}\text { Acanthi llicifolii Herba seu } \\
\text { Radix }\end{array}$ & Alkaloid A & $\begin{array}{l}\text { Down regulating the expressions } \\
\text { of NO and iNOS, and reducing the } \\
\text { expression of protein } \mathrm{p} \text {-ERRK1/2 }\end{array}$ & $\begin{array}{l}\text { Pre-clinical model: Kunming SPF } \\
\text { male (18-22 g) }\end{array}$ & [139] \\
\hline 4 & Piper nigrum L & Piperine & $\begin{array}{l}\text { Antioxidant, anti-inflammatory, and } \\
\text { anti-apoptotic }\end{array}$ & $\begin{array}{l}\text { Pre-clinical model: Swiss mice } \\
(25-30 \mathrm{~g})\end{array}$ & [140] \\
\hline 5 & Capsicum annuum L & Capsaicin & $\begin{array}{l}\text { Inhibiting the inflammatory } \\
\text { response, attenuating oxidative } \\
\text { stress, and reducing hepatocyte } \\
\text { apoptosis }\end{array}$ & $\begin{array}{l}\text { Pre-clinical model: Healthy male } \\
\text { Balb/c mice ( } 6 \text { weeks old, } 18-20 \mathrm{~g} \text { ) }\end{array}$ & [141] \\
\hline 6 & Dendrobium nobile & Dendrobine & Inhibiting miR-295-5p & $\begin{array}{l}\text { Pre-clinical model: ICR (C57BL6) } \\
\text { mice }\end{array}$ & [142] \\
\hline 7 & Nelumbo nucifera & Total alkaloids & $\begin{array}{l}\text { Activation of hepatic AMPK /Nrf2 } \\
\text { cascade }\end{array}$ & $\begin{array}{l}\text { Pre-clinical model: Kunming male } \\
(20-25 \mathrm{~g})\end{array}$ & [143] \\
\hline
\end{tabular}

\section{Other compounds}

Cyanidin-3-O- $\beta$-glucoside (C3G) increases the expression of Gclc in the liver by increasing cAMP levels to activate protein kinase $\mathrm{A}$ (PKA) and then increases the phosphorylation of cAMP response element binding protein (CREB) to promote CREB-DNA binding and increase Gclc transcription. Increased expression of Gclc results in decreased ROS levels and proapoptotic signaling in the liver. In addition, C3G treatment reduces lipid peroxidation in the liver, inhibits the release of proinflammatory cytokines and prevents liver injury [63]. Silymarin is a flavonoid mixture with antioxidant, anti-inflammatory, immunoregulatory, antiproliferative, antiviral and antifibrotic activities. It exerts a good protective effect on liver injury caused by antituberculosis drugs and acetaminophen [64]. Flavonoids with specific anti-DILI activity are shown in Table 1. Moreover, their chemical structures are presented in Fig. 5.

\section{Polysaccharides}

Polysaccharides are present in a wide range of animals and plants and are polymers composed of monosaccharides linked by glycosidic bonds. They participate in various life activities in organisms, mainly by inhibiting free radical-induced damage. They also regulate mitochondrial function and cytokines, inhibit the production of inflammatory mediators and prevent hepatocyte apoptosis [89-91].
In recent years, the ability of polysaccharides to improve the liver tissues of individuals with DILI has also been reported, including those that received APAP [92], antituberculosis drugs (isoniazid and rifampicin) [93], hormone drugs (hydrocortisone) [94] and antitumor drugs (cyclophosphamide, methotrexate, paclitaxel and cisplatin) [95-98]. Animal models have shown good results for candidate drugs in the prevention and treatment of DILI; new drug research and development continues to provide a reliable and feasible basis for DILI treatment.

Polysaccharides in Dendrobium officinale exert a hepatoprotective effect by inhibiting oxidative stress and activating the Nrf2-Keap1 signaling pathway [99]. Kunlun chrysanthemum polysaccharides significantly reduce the expression of caspase- 3 proteins and Bax proteins and increase the expression of $\mathrm{Bcl}-2$ proteins and the Bcl-2/Bax ratio. The mechanism may be related to its anti-inflammatory effects and the regulation of apoptosis-related protein expression [100]. Pachymaran increases the numbers of AKR7A-, c-Jun- and bcl-2-positive cells and decreases the number of Baxlabeled cells in the livers of mice with APAP-induced liver injury. The expression of NF-kB p65 and I B $\alpha$ in liver cells is decreased in a dose-dependent manner [101].

Fucoidan inhibits CYP2E1 overexpression and reduces apoptosis caused by Bax, Bcl-2 and caspase- 3 . It also 


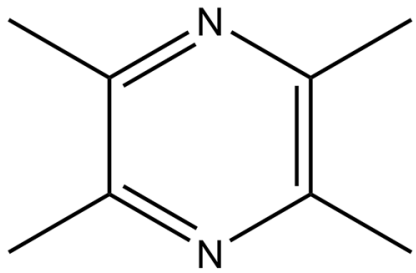

(1)<smiles>COc1ccc2cc3[n+](cc2c1OC)CCc1cc2c(cc1-3)OCO2</smiles>

(4)

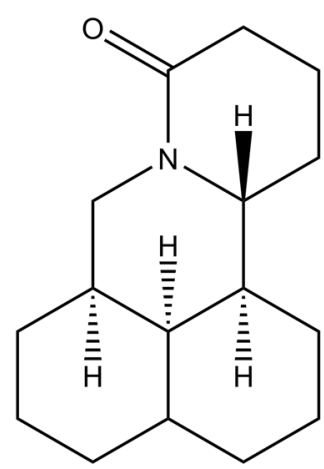

(2)

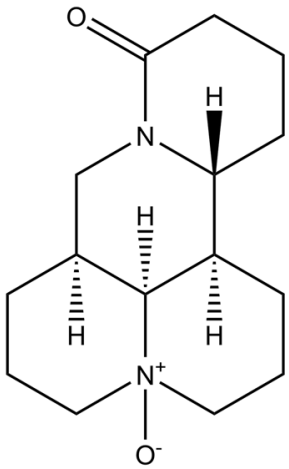

(5)

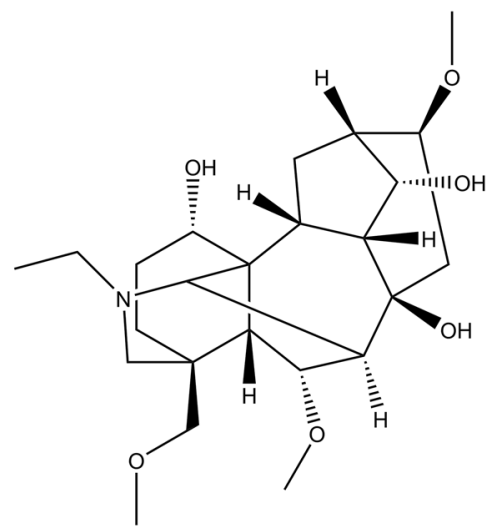

(3)

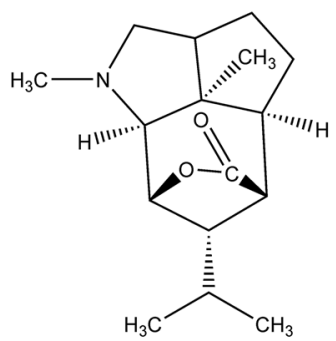

(6)<smiles>COc1cc(CNC(=O)CCCC/C=C/C(C)C)ccc1O</smiles>

(7)<smiles>O=C(/C=C/C=C/c1ccc2c(c1)OCO2)N1CCCCC1</smiles>

(8)

Fig. 6 The chemical structures of Alkaloids showing anti-DILI activity. (1) Ligustrazine; (2) Matrine; (3) Aconine; (4) Berberine; (5) Oxymatrine; (6) Dendrobine; (7) Capsaicin; (8) Piperine

increases the antioxidant capacity (e.g., SOD), GSH-Px activity and GSH content in the liver. It reduces the levels of the inflammatory mediators TNF- $\alpha$ and IL- $1 \beta$ and the activity of iNOS; it also exerts good hepatoprotective effects [102]. SC polysaccharides significantly upregulate GSH expression in mice with liver injury, reduce MDA levels and upregulate the expression of Nrf2 to induce the expression of various detoxification enzymes and antioxidant genes (e.g., HO-1), thus alleviating oxidative stress and injury induced by DILI [103].

Polysaccharides with specific anti-DILI activity are shown in Table 2.

\section{Alkaloids}

Alkaloids are nitrogen-containing alkaline compounds that exist in the biosphere (mainly plants) and have significant biological activities. According to recent studies, many alkaloids exert protective effects on the liver. Berberine significantly reduces hepatic MDA and MPO levels, inhibits JNK phosphorylation and upregulates the expression of $\mathrm{Nrf}-2$ in the nucleus and its downstream gene $\mathrm{Mn}$-SOD. In addition, BBR pretreatment significantly reduces the expression of the proinflammatory cytokines HMGB1 and p-p65 and the cleavage of caspase- 1 and inhibits the infiltration of macrophages and neutrophils, producing a significant preventive effect on DILI [136]. 
Table 4 Anti-DILI effect and mechanism of saponin in natural medicines

\begin{tabular}{|c|c|c|c|c|c|}
\hline No. & Natural medicine & Bioactive components & Mechanisms & The species investigated & References \\
\hline 1 & Astragalus mongholicus & Astragaloside IV & Anti-oxidative & $\begin{array}{l}\text { Pre-clinical model: Male clean } \\
\text { grade ICR mice, (18-22 g) }\end{array}$ & [153] \\
\hline 2 & Terminalia arjuna & Arjunolic acid & $\begin{array}{l}\text { Inhibition of P450-mediated APAP } \\
\text { bioactivation and inhibition of } \\
\text { JNK-mediated activation of mito- } \\
\text { chondrial permeabilization }\end{array}$ & $\begin{array}{l}\text { Pre-clinical model: Male albino } \\
\text { rats of the Wistar strain ( } 4 \text { weeks } \\
\text { old, } 120-130 \mathrm{~g} \text { ) }\end{array}$ & [154] \\
\hline 3 & Acanthopanax sessiliflorus & Chiisanoside & Anti-inflammatory & Pre-clinical model: Mice & [138] \\
\hline 4 & Panax ginseng CA Mey & Ginsenoside RK1 & $\begin{array}{l}\text { Anti-oxidative, anti-apoptosis, } \\
\text { anti-inflammation and anti-nitra- } \\
\text { tive effects }\end{array}$ & $\begin{array}{l}\text { Pre-clinical model: Male ICR mice } \\
\text { ( } 8 \text { weeks old, } 22-25 \mathrm{~g} \text { ) }\end{array}$ & [150] \\
\hline 5 & Panax ginseng CA Mey & Ginsenoside Rg1 & Nrf2 signaling pathway & $\begin{array}{l}\text { Pre-clinical model: Male C57BL/6 } \\
\text { mice (8-10 weeks old, } 20-25 \mathrm{~g})\end{array}$ & [155] \\
\hline 6 & Platycodon grandiflorum & Platypodid D & $\begin{array}{l}\text { NF-KB and AMPK/PI3K/Akt signal- } \\
\text { ing pathways }\end{array}$ & $\begin{array}{l}\text { Pre-clinical model: Male ICR mice } \\
\text { (8-10 weeks old, } 20-22 \mathrm{~g})\end{array}$ & [156] \\
\hline 7 & $\begin{array}{l}\text { Panax notoginseng (Burk.) F. H. } \\
\text { Chen }\end{array}$ & Total saponins & Anti-oxidative & $\begin{array}{l}\text { Pre-clinical model: ICR SPF } \\
\text { mouse, male, }(18-25 \mathrm{~g})\end{array}$ & [157] \\
\hline 8 & Tribulus terrestris $\mathrm{L}$ & Total saponins & $\begin{array}{l}\text { Reducing Caspase- } 3 \text { expression } \\
\text { and inhibiting apoptosis of the } \\
\text { liver cells }\end{array}$ & $\begin{array}{l}\text { Pre-clinical model: Kunming mice } \\
(18-22 \mathrm{~g})\end{array}$ & [158] \\
\hline
\end{tabular}

Aconitine protects hepatocytes from APAP-induced damage by inhibiting mitochondrial dysfunction. Aconitine significantly inhibits the APAP-induced decrease in glutathione levels. The mitochondrial membrane potential and $\mathrm{Bcl}-2$-related protein levels are also decreased, but $\mathrm{Bcl}-2$ and cytochrome-C levels in the mitochondria are increased. Thus, $\mathrm{AC}$ protects hepatocytes from APAP-induced toxicity by inhibiting mitochondrial dysfunction [137]. Ligustrazine exerts a protective effect on APAP-induced acute liver injury by inhibiting oxidative stress and inflammation. Its mechanism may be related to the regulation of $\mathrm{NF}-\mathrm{kB}$ and MAPK signaling pathways [138]. Alkaloids with specific anti-DILI activity are shown in Table 3. Moreover, their chemical structures are presented in Fig. 6.

\section{Saponin}

Saponins are glycosides with a complex structure in the plant kingdom. Saponins are present in ginseng, diosgenin, licorice, notoginseng, Ophiopogon japonicus, Platycodon grandiflorum, Bupleurum and other natural medicines. Saponins display antitumor [144], hypoglycemic [145], cholesterol-lowering [146], hepatoprotective [147], immunoregulatory [148], anti-inflammatory [149] and other biological activities.

Ginsenoside Rk1 significantly reduces the serum levels of ALT, AST, TNF and IL- $1 \beta$ in mice with APAinduced liver injury. Ginsenoside Rk1 inhibits the activation of the apoptotic pathway by increasing Bcl-2 expression and reducing Bax protein expression levels, which significantly reverses APAP-induced liver necrosis and inflammatory cell infiltration [150].

Ginsenoside Rg1 significantly reduces APAP-induced hepatotoxicity and oxidative stress, reduces the expression of the Keap1 protein and upregulates the expression of GCLC, Ugt1a1, Sult2a1 and other genes. The Nrf2 signaling pathway is an important pathway mediating its hepatoprotective effect [151]. Saponins in Platycodon grandiflorum (PGSs) alter the phosphorylation of AMPK and PI3K/Akt, as well as the downstream signals, including the Bcl-2 family, caspase and NF- $\mathrm{kB}$. The mechanism was mainly mediated by the NF- $\mathrm{KB}$ and AMPK/PI3K/Akt signaling pathways [152].

Saponins with specific anti-DILI activity are shown in Table 4. Moreover, their chemical structures are presented in Fig. 7.

\section{Lignans}

Lignans are natural compounds synthesized by the polymerization of phenylpropanoids (C3-C6 monomers), which are widely distributed in various plants and have diverse structures and extensive biological activities. The lignans in Schisandra chinensis (SC) protect the liver and reduce serum ALT levels. For example, schisandrin methyl ester and its analogs are used to treat hepatitis in China [159]. SC lignans induce the hepatic expression of the PXR target genes Cyp3a11 and Ugt1a1, accelerate the metabolism of bile acid and increase the amount of bile acid flowing from liver to intestine or feces [160]. 


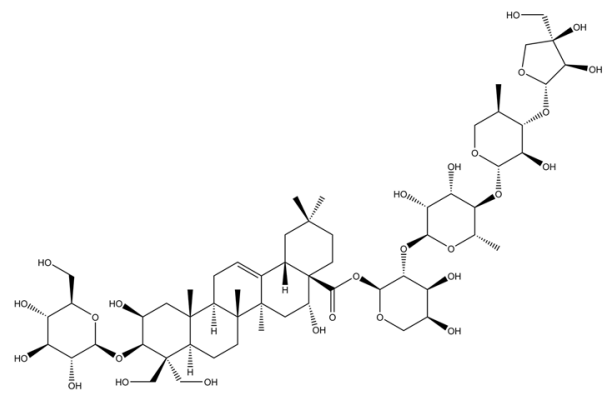

(1)

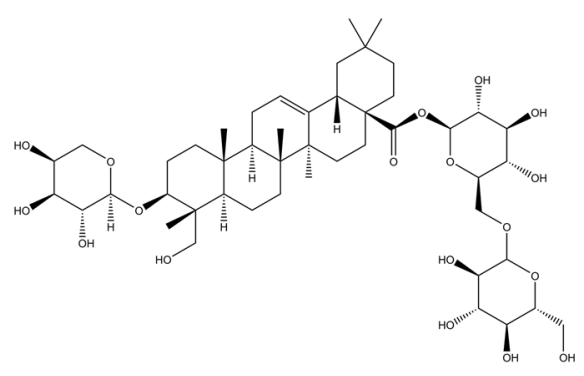

(2)

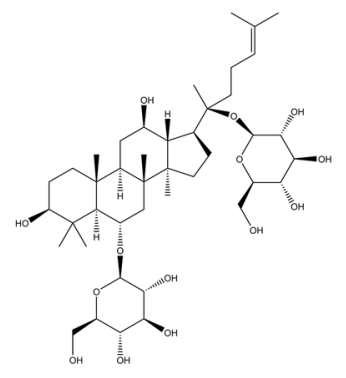

(3)

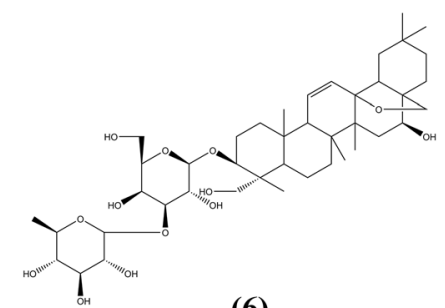

(6)

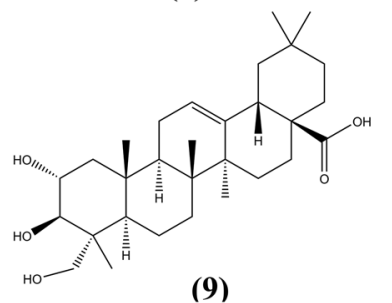

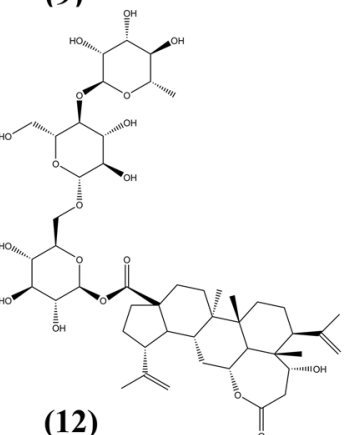

(4)

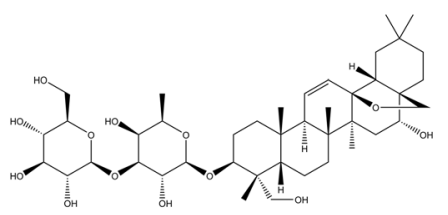

(7)

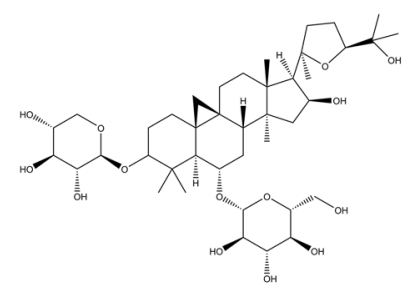

(10)

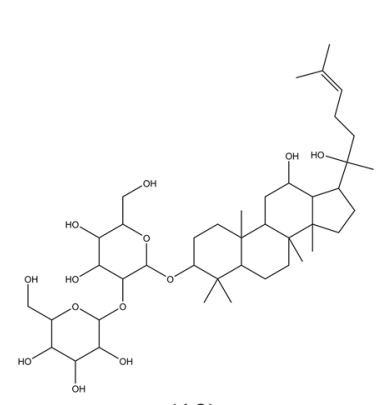

(13)

Fig. 7 The chemical structures of Saponin showing anti-DILI activity. (1) Platycodin D; (2) Akebia saponin D; (3) Ginsenoside Rg1; (4) Ginsenoside Rg5; (5) Ginsenoside Rk1; (6) Saikosaponin A; (7) Saikosaponin D; (8) Geniposide; (9) Arjunolic acid; (10) Astragaloside IV; (11) Ginsenoside Rb1; (12) Chiisanoside; (13) Ginsenoside Rg3 
Table 5 Anti-DILI effect and mechanism of lignans in natural medicines

\begin{tabular}{|c|c|c|c|c|c|}
\hline No. & Natural medicine & Bioactive components & Mechanisms & The species investigated & References \\
\hline 1 & Mangnolia officinalis & Magnolol & Anti-oxidative & $\begin{array}{l}\text { Pre-clinical model: Male SD rat } \\
(200-250 \mathrm{~g})\end{array}$ & [162] \\
\hline 2 & $\begin{array}{l}\text { Schisandra sphenan- } \\
\text { thera }\end{array}$ & Lignans extract & Regulation of lipid metabolism & $\begin{array}{l}\text { Pre-clinical model: Male } \\
\text { C57BL/6 J mice ( } 6 \text { weeks, } \\
18-20 \text { g) }\end{array}$ & [163] \\
\hline 3 & $\begin{array}{l}\text { Schisandra sphenan- } \\
\text { thera }\end{array}$ & Schisandrol B & $\begin{array}{l}\text { Attenuated the increases in ALT } \\
\text { and AST activity, inhibiting the } \\
\text { activities of CYP2E1 and CYP3A11. } \\
\text { Abrogated APAP-induced } \\
\text { activation of p53 and p21, and } \\
\text { increased expression of liver } \\
\text { regeneration and antiapoptotic- } \\
\text { related proteins such as Cyclin D1 } \\
\text { (CCND1), PCNA, and BCL-2 }\end{array}$ & $\begin{array}{l}\text { Pre-clinical model: Male C57BL/6 } \\
\text { mice (6-8 weeks old, 20-22 g) }\end{array}$ & [164] \\
\hline 4 & Schisandra fructus & $\begin{array}{l}\text { Schisandrin A, Schisandrin B, } \\
\text { Schisandrin C, Schisandrol A, } \\
\text { Schisandrol B, and Schisantherin } \\
\text { A }\end{array}$ & $\begin{array}{l}\text { Inhibited the enzymatic activi- } \\
\text { ties of three CYP450 isoforms } \\
\text { (CYP2E1, CYP1A2, and CYP3A11) } \\
\text { related to APAP bioactivation, and } \\
\text { further decreased the forma- } \\
\text { tion of APAP toxic intermediate } \\
\mathrm{N} \text {-acetyl-p-benzoquinone imine } \\
\text { (NAPQI) in mouse microsomal } \\
\text { incubation system }\end{array}$ & $\begin{array}{l}\text { Pre-clinical model: Male C57BL/6 } \\
\text { mice (6-8 weeks old, } 20-22 \mathrm{~g} \text { ) }\end{array}$ & [165] \\
\hline 5 & Schisandra fructus & Schisandrin B & Induction of HSP27 and HSP70 & $\begin{array}{l}\text { Pre-clinical model: Male Insti- } \\
\text { tute of Cancer Research mice } \\
(18-22 \mathrm{~g})\end{array}$ & {$[166]$} \\
\hline
\end{tabular}

Gomisin N promotes liver sirtuin1 (SIRT1)-AMPK signaling, activates PPAR $\alpha / \mathrm{PGC}-1 \alpha$, promotes fatty acid $\beta$ oxidation, downregulates CYP2E1, upregulates antioxidant gene expression, inhibits inflammatory gene expression, and inhibits reactive oxygen species generation. In addition, GN prevents the decrease in SIRT1 signaling and AMPK phosphorylation to alleviate liver injury [161].

Lignans with specific anti-DILI activity are shown in Table 5. Moreover, their chemical structures are presented in Fig. 8.

\section{Terpene}

Terpenoids are natural compounds produced from isoprene or isoprane through various pathways. They are the main components of volatile oil and are widely distributed in nature. According to the number of isoprene units present in their structures, they are divided into monoterpenes, sesquiterpenes, diterpenes and triterpenes [167].

Citronella essential oil reduces the levels of ALT, AST, ALP, and MPO activity and NO production, inhibits the migration of neutrophils in mice with APAP-induced liver injury and shows antioxidant activity, thus ameliorating APAP-induced liver toxicity [168]. Astaxanthin inhibits the TNF- $\alpha$-mediated JNK signaling pathway and the phosphorylation of ERK and P38, prevents ROS generation, inhibits oxidative stress, reduces hepatocyte necrosis, protects the liver and alleviates DILI [169]. Kamebakaurinecan significantly reduces ALT and AST levels and protects against DILI by inhibiting inflammation and oxidative stress [170].

Terpenes with specific anti-DILI activity are shown in Table 6. Moreover, their chemical structures are presented in Fig. 9.

\section{Others}

Auricularia auricula extract exerts antioxidant and protective effects on APAP-induced liver injury. The mitochondria-targeted antioxidant effects of chlorogenic acid may be one of its mechanisms [174]. Tovophylin A (TA) inhibits APAP-induced lipid peroxidation and improves the liver antioxidant capacity. It increases the mRNA expression of nuclear red blood cell-related factor 2 (Nrf2) and its target genes, inhibits the activation of nuclear factor- $\mathrm{kB}(\mathrm{NF}-\mathrm{\kappa} \mathrm{B})$ and subsequently induces proinflammatory cytokine production to exert a significant protective effect on APAP-induced hepatotoxicity [175].

Acalypha wilkesiana extract significantly reduces TLR3 and TLR4 expression, thus activating MAPKs and NF $-\kappa B$ to reduce the levels of liver injury indicators and proinflammatory factors at the protein and gene levels to attenuate APAP-induced liver injury [176]. 


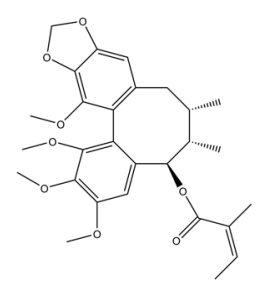

(1)

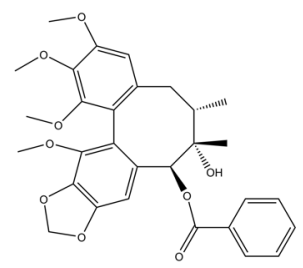

(5)

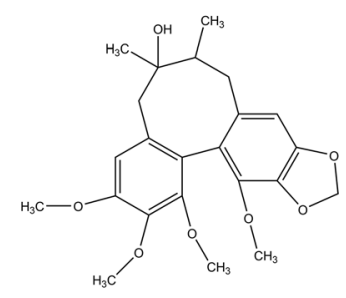

(9)

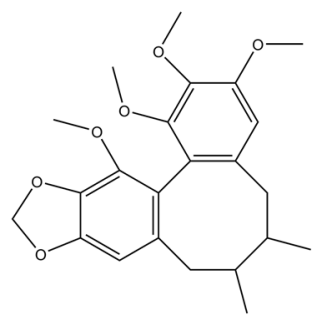

(13)

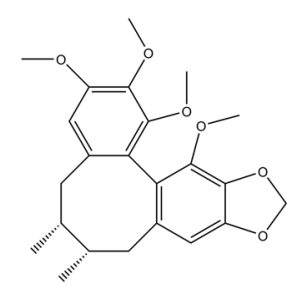

(2)

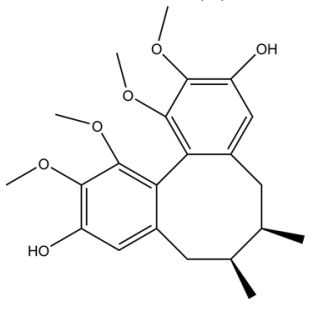

(6)

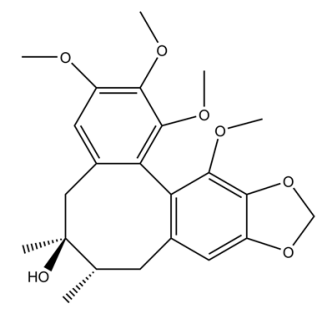

(10)

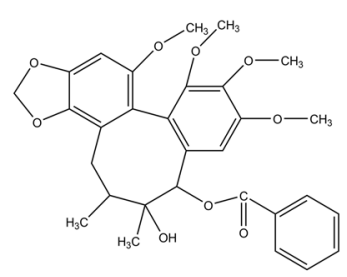

(14)

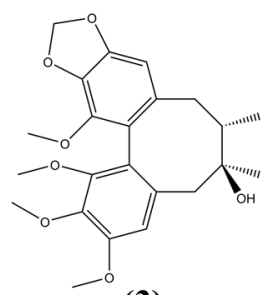

(3)

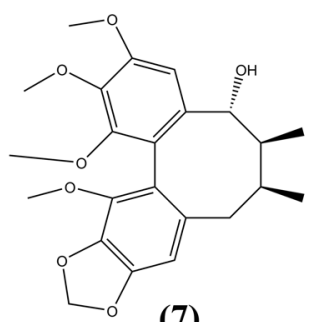

(7)

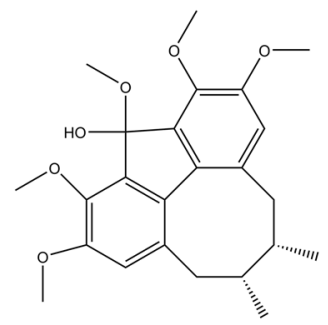

(11)

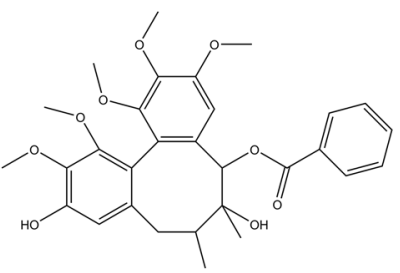

(15)

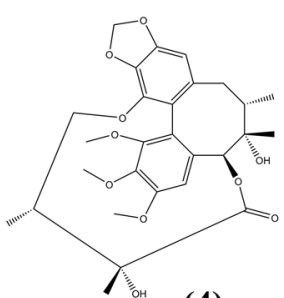

(4)

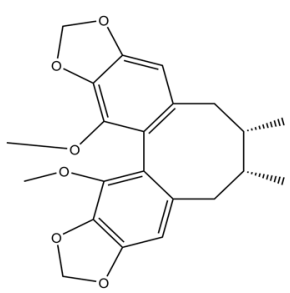

(8)

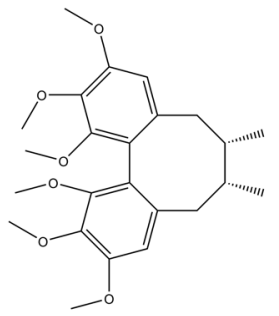

(12)

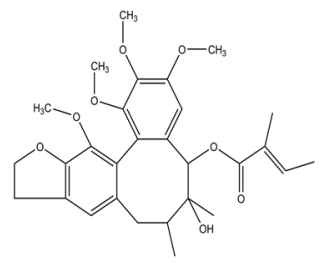

(16)

Fig. 8 The chemical structures of lignans showing anti-DILI activity. (1) Angeloylgomisin O; (2) Gomisin N; (3) Schizandrol B; (4) Gomisin D; (5) Gomisin G; (6) Gomisin J; (7) Gomisin O; (8) Schisandrin C; (9) Schizandrol A; (10) Gomisin A; (11) Schisanhenol; (12) Schisandrin A; (13) Schizandrin B; (14) Schisantherin A; (15) Schisantherin $E_{;}$(16) Schisantherin B

Tannic acid possesses antioxidant, anti-inflammatory and anti-apoptotic properties. Tannic acid inhibits excess IL-1 $\beta$, TNF- $\alpha$, c-fos, c-jun, NF-kB p65 and caspase-3 accumulation, inhibits $\mathrm{Nrf} 2$ and $\mathrm{HO}-1$, and exerts significant hepatoprotective effects on APAPinduced hepatotoxicity [177]. Some polyphenols also reduce DILI by inhibiting the activities of the CYP2E1 and CYP1A2 enzymes [178]. Other bioactive components that inhibit DILI and have been identified to date are shown in Table 7.

\section{The clinical application of natural drugs}

In clinical practice, the use of single medications to treat DILI is infrequent (i.e., mainly for natural drug combinations), but their use for the treatment of antituberculosis drug-induced liver injury is relatively more frequent. This research is summarized in Table 8. Natural drugs and their combinations used to treat DILI were preliminarily investigated. It was found that the use frequency of natural drugs (e.g., SC, Glycyrrhiza uralensis and Artemisia capillaris) was high, with great exploration potential and application prospects. 
Table 6 Anti-DILI effect and mechanism of terpenes in natural medicines

\begin{tabular}{|c|c|c|c|c|c|}
\hline No. & Natural medicine & Bioactive components & Mechanisms & The species investigated & References \\
\hline 1 & Nigella sativa Linn & Thymoquinone & $\begin{array}{l}\text { Decreases the level of protein } \\
\text { and mRNA expression of a-SMA, } \\
\text { collagen-I and the TIMP-1 to } \\
\text { down-regulate TLR4 expression and } \\
\text { significantly reducing the level of } \\
\text { pro-inflammatory cytokines. Inhibits } \\
\text { the phosphorylation of PI3K, } \\
\text { enhances the phosphorylation of } \\
\text { AMPK and LKB-1 }\end{array}$ & $\begin{array}{l}\text { Pre-clinical model: Male Kunming } \\
\text { mice ( } 6 \text { weeks old; } 18-23 \mathrm{~g} \text { ) }\end{array}$ & [171] \\
\hline 2 & $\begin{array}{l}\text { Haematococcus } \\
\text { pluvialis }\end{array}$ & Astaxanthin & $\begin{array}{l}\text { Alleviating hepatocyte necrosis, } \\
\text { blocking ROS generation, inhibiting } \\
\text { oxidative stress, and reducing apop- } \\
\text { tosis by inhibiting the JNK signaling } \\
\text { pathway mediated by TNF-a and } \\
\text { phosphorylation of ERK and P38 }\end{array}$ & $\begin{array}{l}\text { Pre-clinical model: male C57BL/6 } \\
\text { mice }\end{array}$ & {$[169]$} \\
\hline 3 & Rabdosia excisa. KA & Kamebakaurin & $\begin{array}{l}\text { Inhibiting the inflammatory } \\
\text { response and oxidative stress }\end{array}$ & $\begin{array}{l}\text { Pre-clinical model: female C57BL/6 J } \\
\text { mice ( } 6 \text { weeks old) }\end{array}$ & {$[170]$} \\
\hline 4 & Bouvardia ternifolia & Ursolic acid and oleanolic acid & $\begin{array}{l}\text { The levels of AST and ALT were } \\
\text { significantly reduced }\end{array}$ & $\begin{array}{l}\text { Pre-clinical model: male Balb/C } \\
\text { mice }(23-27 \mathrm{~g})\end{array}$ & {$[172]$} \\
\hline 5 & Bacopa monnieri & Bacoside & $\begin{array}{l}\text { Prevent lipid peroxidation and } \\
\text { prevent free radicals }\end{array}$ & $\begin{array}{l}\text { Pre-clinical model: female Wistar } \\
\text { albino rats (170-200 g) }\end{array}$ & {$[173]$} \\
\hline
\end{tabular}

The authors further systematically reviewed SC and found that $\mathrm{SC}$ is a natural drug with great potential for the treatment of DILI. Its active components significantly improve the liver function of patients and exert significant therapeutic effects on DILI, with few reported adverse reactions. Thus, SC may be a very important and effective treatment from DILI. As many as 10 related preparations based on SC or its bioactive components have been widely used in the clinical treatment of elevated transaminase levels caused by various liver diseases. Examples include bicyclol, bifendate, gandening, Wuzhi capsules and Liuwei Wuling tablets.

The researchers studied 72 patients with liver injury caused by antituberculosis drugs. According to different methods of treating liver injury, the patients were divided into 37 patients in the observation group and 35 patients in the control group. The control group was treated with diammonium glycyrrhizinate, and the observation group was treated with bicyclol tablets. The total clinical effective rate of the observation group was significantly higher than that of the control group. After treatment, the levels of ALT, AST and TBIL in the two groups were lower than those before treatment, and the levels in the observation group were lower than those in the control group. Both treatments exert a good hepatoprotective effect, but the effect of bicyclol is better than diammonium glycyrrhizinate [188]. Liu observed the clinical efficacy of Liuwei Wuling tablets in preventing DILI caused by anti-TB drugs. Liuwei Wuling tablets were administered to the treatment group, and glucuronolactone tablets were administered to the control group. The occurrence of liver injury in the two groups was observed. One patient in the treatment group was diagnosed with liver injury and four patients in the control group had liver injury, with incidence rates of $6.7 \%$ and $26.7 \%$, respectively, indicating that Liuwei Wuling tablets effectively prevent druginduced liver injury caused by anti-TB drugs [189].

The mechanism by which Liuwei Wuling tablets treat DILI may be attributed to their anti-inflammatory and antioxidant properties. Liuwei Wuling tablets inhibit the expression of the inflammatory factors high mobility group protein 1 (HMGB1), TNF- $\alpha$ and IL- $1 \beta$, increases GSH and SOD activities, and reduces MDA and triglyceride (TG) levels in the liver tissue [190]. In addition, Liuwei Wuling tablets inhibit the increase in the Th1 cell ratio and promote an increase in the Th2 cell ratio in mice to restore the Th1/Th2 balance and reduce liver injury [191]. 


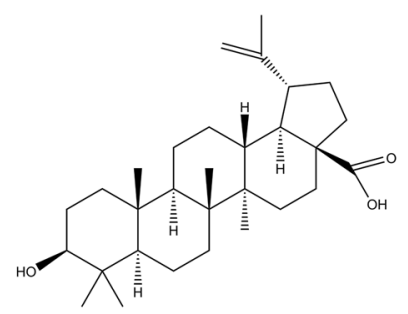

(1)<smiles>C=C1CC[C@]2(CO)[C@@](C)(CO)[C@@H](C)CC[C@]2(C)[C@H]1CC=C1C(=O)OC[C@@H]1O</smiles>

(4)<smiles>C=C1CCC[C@]2(C)C=C3OC(=O)C(C)=C3C[C@H]12</smiles>

(2)<smiles>O=C1CC(c2ccc(O)cc2)Oc2cc(O)ccc21</smiles>

(5)<smiles>CC1=CC(=O)C(C(C)C)=CC1=O</smiles>

(3)

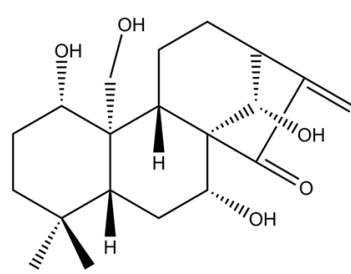

(6)<smiles>CC1=C(/C=C(C)/C=C(C)/C=C/C=C(C)/C=C/C=C/C=C(C)/C=C/C=C(C)/C=C/C2=C(C)C(=O)[C@H](C)CC2(C)C)C(C)(C)C[C@H](O)C1=O</smiles>

(7)<smiles>CC1=CC(=O)C(C(C)C)=CC1=O</smiles>

(9)

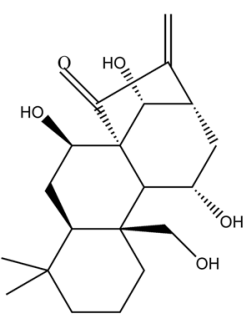

(10)

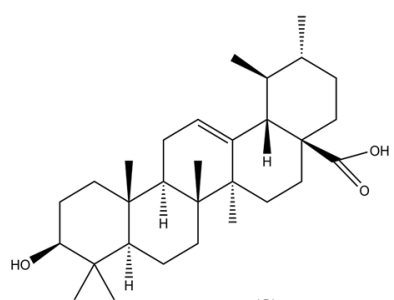

(8)

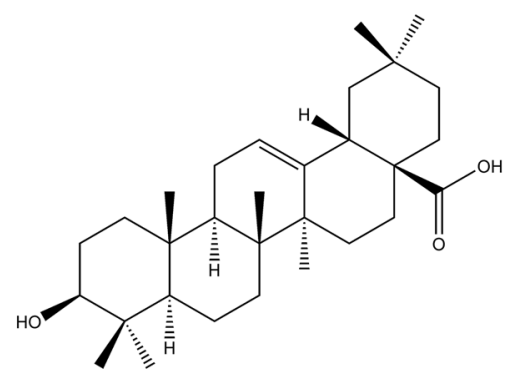

(11)

Fig. 9 The chemical structures of terpene showing anti-DILI activity. (1) Betulinic acid; (2) Atracylenolide-1; (3) Thymoquinone; (4) Andrographis; (5) Liquiritigenin; (6) Kamebakaueine; (7) Ursolic; (8) Astaxanthin; (9) Thymoquinone; (10) Kamebakaurin; (11) Oleanolic acid

\section{Limitations and future prospects}

The purpose of establishing the control group in a clinical trial is to judge whether the changes observed in subjects before and after treatment are caused by the test drug or other factors. Randomized controlled trials are the most rigorous and reliable scientific method to evaluate the effects of medical intervention measures. The scientific and reasonable establishment of the control group is one of the most important steps in the design of clinical research, which is directly related to the results and conclusions of the research.

Natural drugs may exert a protective effect on DILI by inhibiting lipid peroxidation, promoting the recovery of the liver cell membrane, eliminating oxygen free radicals, inhibiting mitochondrial dysfunction, ameliorating cholestasis, restoring a balanced $\mathrm{Ca}^{2+}$ concentration and inhibiting the secretion of inflammatory factors. Due to the diversity of chemical components in natural drugs, they have many targets in the treatment of diseases. The same component may 
Table 7 Anti-DILI effect and mechanism of extract for natural medicines

\begin{tabular}{|c|c|c|c|c|c|}
\hline No. & Natural medicine & Bioactive components & Mechanisms & The species investigated & References \\
\hline 1 & Mucuna pruriens & Ethanol extract & Anti-oxidative & $\begin{array}{l}\text { Pre-clinical model: adult Wistar } \\
\text { albino mice (15-20 g) and rats } \\
(100-200 \mathrm{~g}) \text {, either sex }\end{array}$ & [179] \\
\hline 2 & $\begin{array}{l}\text { Solanum xanthocarpum } \\
\text { Fruit }\end{array}$ & $50 \%$ ethanol extract & $\begin{array}{l}\text { Anti-inflammatory, hepatopro- } \\
\text { tective activity }\end{array}$ & $\begin{array}{l}\text { Pre-clinical model: wistar rats } \\
(150-170 \mathrm{~g}) \text { and Swiss albino } \\
\text { mice }(25-30 \mathrm{~g}) \text { of either sex }\end{array}$ & [180] \\
\hline 3 & Salvia miltiorrhiza & Water extract & $\begin{array}{l}\text { maintenance of mitochondrial } \\
\text { metabolic activity, CYP2E1 } \\
\text { inhibition, reduction of total } \\
\text { glutathione depletion }\end{array}$ & $\begin{array}{l}\text { Pre-clinical model: male SD rats } \\
(260-280 \mathrm{~g})\end{array}$ & [181] \\
\hline 4 & Moringa oleifera Lam & Ethanol extract & Anti-oxidative & $\begin{array}{l}\text { Pre-clinical model: male Wistar } \\
\text { rats of (180-220 g) }\end{array}$ & [182] \\
\hline 5 & Pinellia ternate (Thunb) Breit & Water extract & Anti-oxidative and regulate Nrf2 & $\begin{array}{l}\text { Pre-clinical model: male ICR mice } \\
(18-22 \mathrm{~g})\end{array}$ & [183] \\
\hline 6 & Garcinia mangostana L. & Acetone extract & $\begin{array}{l}\text { Activate Nrf2 and inhibit NF-KB } \\
\text { signaling pathways }\end{array}$ & $\begin{array}{l}\text { Pre-clinical model: male BALB/c } \\
\text { mice }(20-30 \mathrm{~g})\end{array}$ & {$[175]$} \\
\hline 7 & $\begin{array}{l}\text { Schisandfa chinensis (Turcz.) } \\
\text { Baill }\end{array}$ & Extract & Active of Nrf2 signal pathway & $\begin{array}{l}\text { Pre-clinical model: SPF SD rat, } \\
(160-200) \mathrm{g}\end{array}$ & [184] \\
\hline 8 & Phyllanthus emblica L. & Extract & $\begin{array}{l}\text { Active of Nrf2 /ARE signaling } \\
\text { pathway }\end{array}$ & $\begin{array}{l}\text { Pre-clinical model: male } \\
\text { C57BL/6 J mice (5-8 weeks old, } \\
18-22 \text { g) }\end{array}$ & [185] \\
\hline 9 & Trapa natans & $50 \%$ ethanolic extract & $\begin{array}{l}\text { Normalizes the altered liver } \\
\text { marker enzymes and antioxidant } \\
\text { defense status }\end{array}$ & $\begin{array}{l}\text { Pre-clinical model: adult Wistar } \\
\text { male rats (140-180 g) }\end{array}$ & [186] \\
\hline 10 & $\begin{array}{l}\text { Auricularia delicata (Fr.) } \\
\text { Henn }\end{array}$ & $\begin{array}{l}\text { Hexane, chloroform, ethyl } \\
\text { acetate, and methanol } \\
\text { extract }\end{array}$ & Anti-oxidative & Pre-clinical model: male rat & [187] \\
\hline
\end{tabular}

have multiple targets, and both common and different targets have been identified among different components. The components exert both independent and synergistic effects. Limited clinical trials investigating these drugs have mainly used natural drug combinations. Although the curative effect is accurate, the specific drugs and their mechanisms of action are difficult to explain. At present, most drugs have been analyzed in animal experiments and require further verification. Nevertheless, they still have a certain reference value.

\section{Conclusion}

Natural drugs are a natural treasure worth developing and utilizing as new drugs. Drug development with natural drugs as the main raw material will be an important method to treat DILI in the future. We hope that this review provides a scientific basis for understanding existing products and prescriptions, further clarifies market positioning and provides a reference for the development of drugs for DILI. 


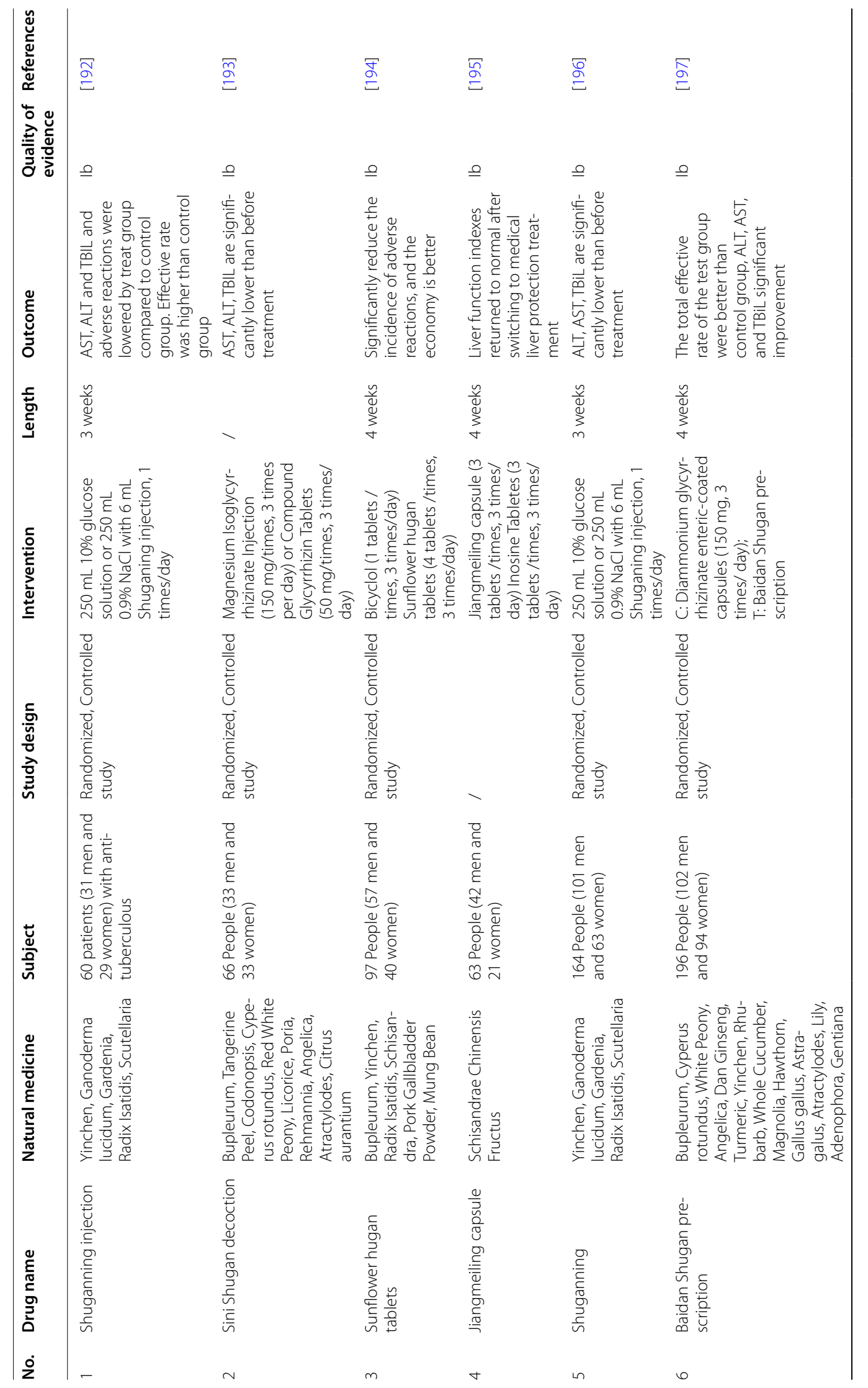




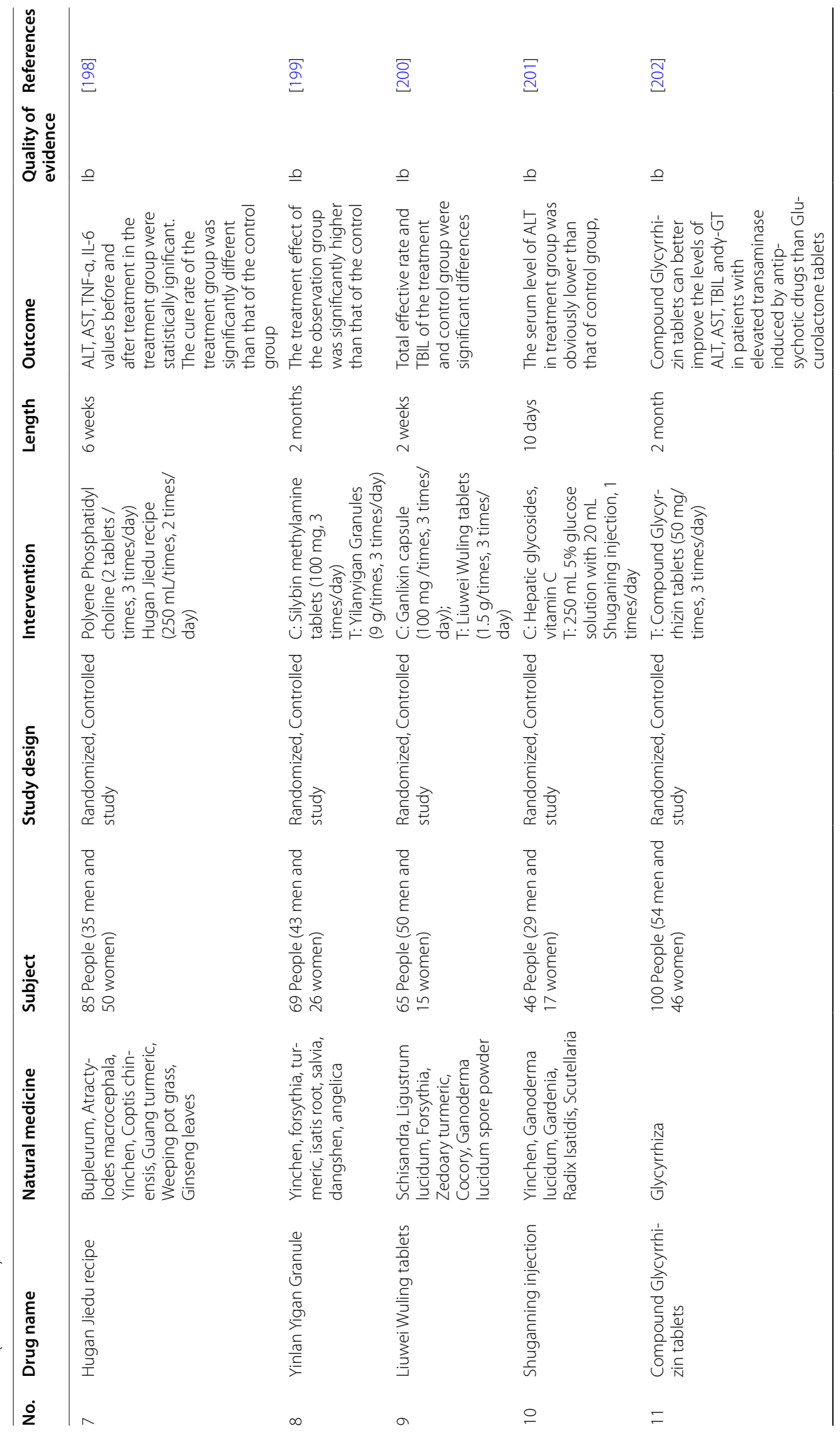




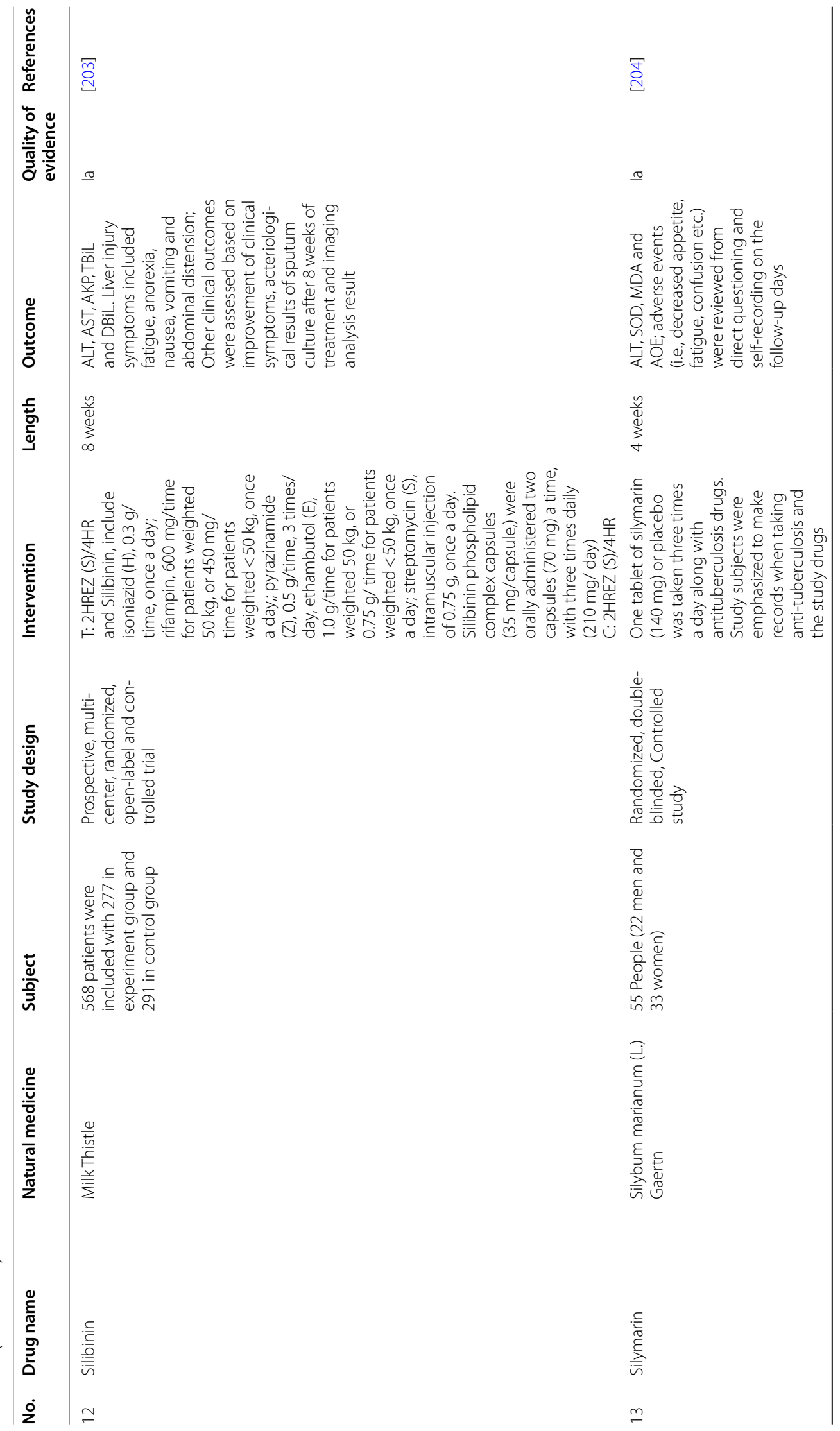




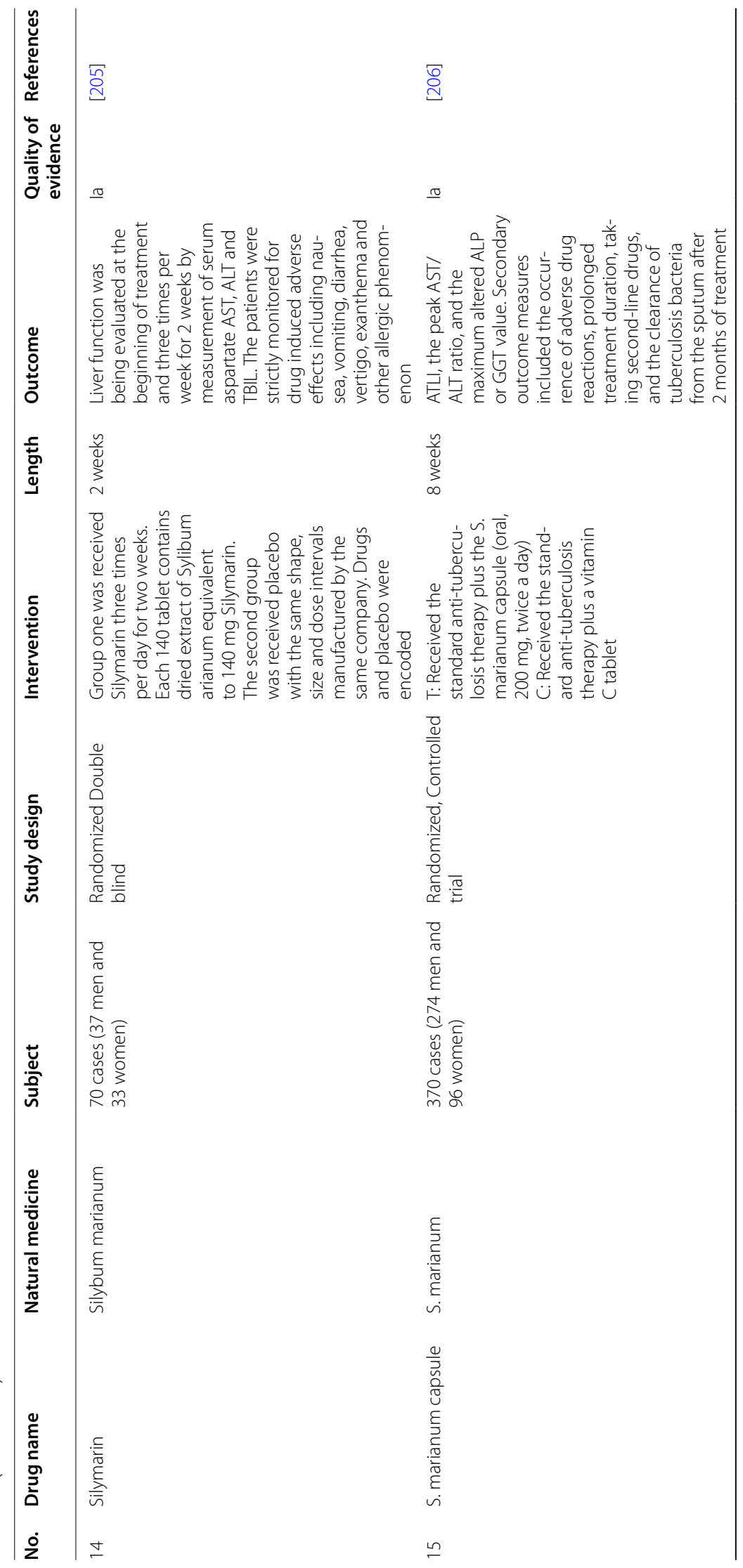




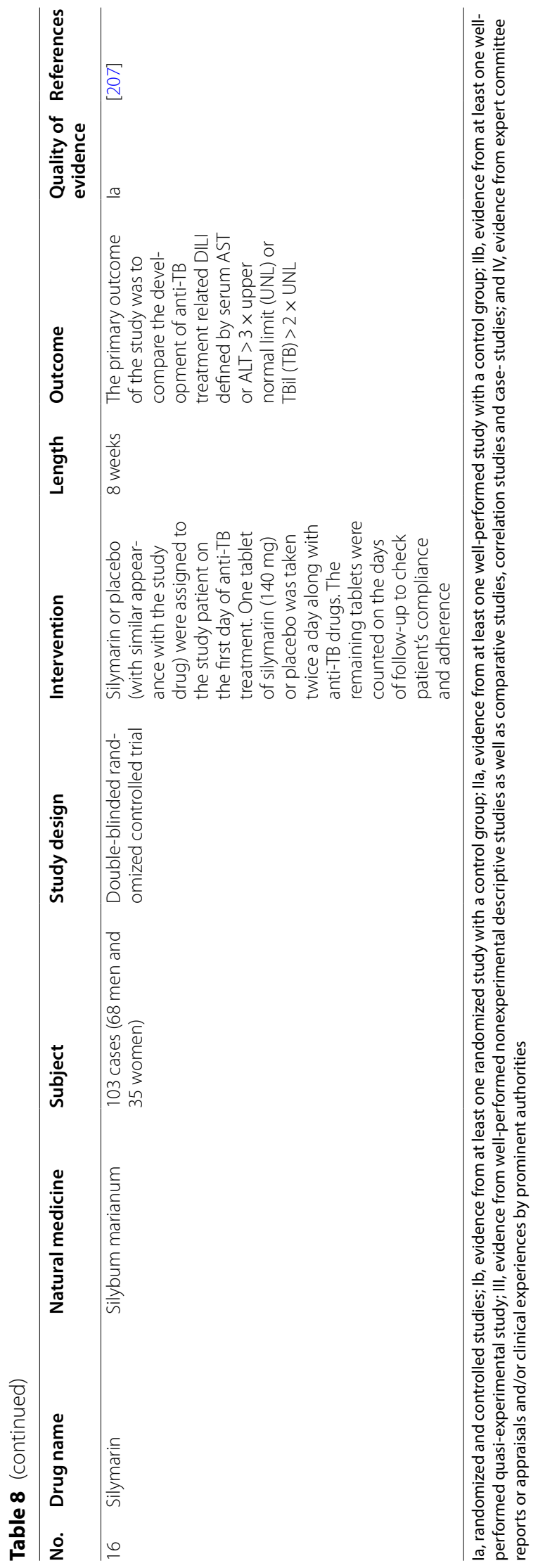




\begin{abstract}
Abbreviations
ALR: Aug-menter of liver regeneration; ATP: Adenosine triphosphate; AMPK: Amp-dependent protein kinase; ALT: Alanine aminotransferase; AST: Aspartate aminotransferase; ARE: Antioxidant responsive element; ADR: Adverse drug reaction; ATDILI: Anti-tuberculosis DILI; APAP: Acetaminophen; AMPK/Nrf2: Adenosine 5'-monophosphate (AMP)-activated protein kinase/nuclear respiratory factor2; BCL-2: B-cell lymphoma-2; CYP3A: Cytochrome P450 3A; CD1: Cyclin D1; DILI: Drug-induced liver injury; ERK: Extracellular regulated protein kinases; GSH: Glutathione; GSH-Px: Glutathione peroxidase; HSP27: Heat shock protein 27; HSP70: Heat shock protein 70; iNOS: Inductible Nitric Oxide Synthase; DHM: Dihydromyricetin; HO-1: Heme oxygenase-1; HILI: Herb-induced liver injury; INH: Isoniazid; IL-1 ß: Interleukin-1; IL-6: Interleukin-6; JNK: C-Jun $\mathrm{N}$-terminal kinase; NSAIDs: LKB, liver kinase B; KT: Ketoconazole Non-steroidal anti-inflammatory drugs; MTX: Methotrexate; MDA: Malondialdehyde; NAPQI: $\mathrm{N}$-acetyl-p-benzoquinoneimine; NRF2: Nuclear respiratory factor2; NF-KB: The master immune transcription factor nuclear factor kappa B; NO: Nitric Oxide; PI3K: Phosphoinositide 3-kinase; PKA: Protein kinase A; PCNA: Proliferating Cell Nuclear Antigen; PGSs: Platycodon grandiflorum; RFP: Rifampicin; PCNA: Proliferating cell nuclear antigen; ROS: Reactive oxygen species; SOD: Superoxide dismutase; SC: Schisandra chinensis; TNF: Tumour necrosis factor; TVX: Trovafloxacin; TNF-a: Tumor necrosis factor-alpha; TLR4: Toll-like receptors 4; TG: Triglyceride.
\end{abstract}

\section{Acknowledgements}

The authors would like to thank the reviewers and also the authors of all references.

\section{Authors' contributions}

$Y Z$, JW and DZ conducted the analytical part, wrote the manuscript. JL and QW downloaded the reference and processed the graph and the table in the manuscript. JC, PT, BX, YH collected the data. PZ, XX and JP conceived and coordinated the study, and critically evaluated the data. All authors read and approved the final manuscript.

\section{Funding}

This research is supported by National Key R\&D Program of China (No. 2018YFC1706502), National Natural Science Foundation Youth Fund Project (U19A2010, 81803669), National Key R\&D Program of Sichuan province (2020YFN0152), Research team of traditional Chinese medicine Germplasm Resources (CXTD2018003).

\section{Availability of data and materials}

All data are available in the manuscript and they are showed in figures and tables.

\section{Declarations}

\section{Ethics approval and consent to participate}

Not applicable.

\section{Consent for publication}

Not applicable.

\section{Competing interests}

The authors declare that they have no conflict of interest.

\section{Author details}

${ }^{1}$ College of Pharmacy, Chengdu University of Traditional Chinese Medicine, 1166 Liutai Avenue, Wenjiang District, Chengdu 611137, Sichuan, China. ${ }^{2}$ School of Chinese Pharmacy, Beijing University of Chinese Medicine, Beijing 102488, China. ${ }^{3}$ Department of Pharmacy, Medical Supplies Center of PLA General Hospital, 100\#, West 4th Ring Middle Rd., Fengtai, Beijing 10039, China. ${ }^{4}$ Department of Liver Disease, Fifth Medical Center of PLA General Hospital, 100\#, West 4th Ring Middle Rd., Fengtai, Beijing 10039, China.

Received: 3 September 2021 Accepted: 21 November 2021 Published online: 11 December 2021

\section{References}

1. Chalasani NP, Maddur H, Russo MW, Wong RJ, Reddy KR. ACG clinical guideline: diagnosis and management of idiosyncratic drug-induced liver injury. Am J Gastroenterol. 2021;116:878-98. https://doi.org/10. 14309/ajg.0000000000001259.

2. Hayashi PH, Bjornsson ES. Long-term outcomes after drug-induced liver injury. Curr Hepatol Rep. 2018;17:292-9. https://doi.org/10.1007/ s11901-018-0411-0.

3. Hoofnagle JH, Serrano J, Knoben JE, Navarro VJ. LiverTox: a website on drug-induced liver injury. Hepatology. 2013;57:873-4. https://doi.org/ 10.1002/hep.26175.

4. Larrey D. Epidemiology and individual susceptibility to adverse drug reactions affecting the liver. Semin Liver Dis. 2002;22:145-55. https:// doi.org/10.1055/s-2002-30105.

5. Watkins PB, Seeff LB. Drug-induced liver injury: summary of a single topic clinical research conference. Hepatology. 2006;43:618-31. https:// doi.org/10.1002/hep.21095.

6. Bell LN, Chalasani N. Epidemiology of idiosyncratic drug-induced liver injury. Semin Liver Dis. 2009;29:337-47. https://doi.org/10.1055/s-00291240002.

7. Björnsson E. Review article: drug-induced liver injury in clinical practice. Aliment Pharmacol Ther. 2010;32:3-13. https://doi.org/10.1111/j.13652036.2010.04320.x.

8. Vega M, Verma M, Beswick D, Bey S, Hossack J, Merriman N, Shah A, Navarro V, Drug Induced Liver Injury Network (DILIN). The incidence of drug- and herbal and dietary supplement-induced liver injury: preliminary findings from gastroenterologist-based surveillance in the population of the state of Delaware. Drug Saf. 2017:40:783-7. https:// doi.org/10.1007/s40264-017-0547-9.

9. Shen T, Liu YX, Shang J, Xie Q, Li J, Yan M, Xu JM, Niu JQ, Liu JJ, Watkins PB, Aithal GP, Andrade RJ, Dou XG, Yao LF, Lv FF, Wang Q, Li YG, Zhou XM, Zhang YX, Zong PL, Wan B, Zou ZS, Yang DL, Nie YQ, Li DL, Wang YY, Han XA, Zhuang H, Ma YM, Chen CW. Incidence and etiology of drug-induced liver injury in mainland China. Gastroenterology. 2019;156:2230-41. https://doi.org/10.1053/j.gastro.2019.02.002.

10. Zhuang MZ, Wang YP, Zhang X, Zhang ZY, Yuan RH, Zhu Y, Zhou F, Guo $Z W$. Clinical efficacy of Hugan Jiedu decoction against drug induced liver injury and related inflammatory cytokines (HJD). Chin J Integr Trad West Med Dig. 2016;24:26-8. https://doi.org/10.3969/j.issn.1671-038X. 2016.01.07.

11. Yang XM, Shen BR, Liu PY, Yang KN, Zhao Q, Wang ZK. Logistic regression analysis of risk factors of antituberculosis drug-induced liver injury. Chin J Hospital Pharm. 2019;39:67-71. https://doi.org/10.13286/j.cnki. chinhosppharmacyj.2019.01.15.

12. Sun Q, Zhang Q, Gu J, Sun WW, Wang P, Bai C, Xiao HP, Sha W. Prevalence, risk factors, management, and treatment outcomes of first-line antituberculous drug-induced liver injury: a prospective cohort study. Pharmacoepidemiol Drug Saf. 2016;25:908-17. https://doi.org/ 10.1002/pds.3988.

13. He T, Wang F, Tang W. Logistic regression analysis of risk factors of antituberculosis drug-induced liver injury. China Pharm. 2016;27:1626-8. https://doi.org/10.6039/j.issn.1001-0408.2016.12.15.

14. Xiong XM, Li L, Wang B. Progress in genetic polymorphism of druginduced liver injury. Chin J Hospital Pharm. 2020;40:827-30. https:// doi.org/10.13286/j.1001-5213.2020.07.23.

15. Yang S, Hwang SJ, Park JY, Chung EK, Lee Jl. Association of genetic polymorphisms of CYP2E1, NAT2, GST and SLCO1B1 with the risk of anti-tuberculosis drug-induced liver injury: a systematic review and meta-analysis. BMJ Open. 2019;9: e027940. https://doi.org/10.1136/ bmjopen-2018-027940.

16. Zhang CY, Jiao L, Bai H, Zhao ZZ, Hu XJ, Wang MJ, Wu T, Peng W, Liu TYH, Song JJ, Zhou J, Li MJ, Lyv MY, Zhang JW, Chen H, Chen J, Ying BW. Association of POR and PPARa polymorphisms with risk of anti-tuberculosis drug-induced liver injury in Western Chinese Han population. Infect Genet Evol. 2020;79: 104147. https://doi.org/10. 1016/j.meegid.2019.104147.

17. Fernández-Villar A, Sopeña B, Fernández-Villar J, Vázquez-Gallardo R, Ulloa F, Leiro V, Mosteiro M, Piñeiro L. The influence of risk factors on the severity of anti-tuberculosis drug-induced hepatotoxicity. Int J Tuberc Lung Dis. 2004;8(12):1499-505. 
18. Jussi JS, David LC, Robert MJ, Steven S, John AJ, Charles MN, Charles AP, Fred MG, David N, Dorothy BS, John B, Raman V, Timothy RS, ATS (American Thoracic Society) Hepatotoxicity of Antituberculosis Therapy Subcommittee. An official ATS statement: hepatotoxicity of antituberculosis therapy. Am J Respir Crit Care Med. 2006;174(8):93552. https://doi.org/10.1164/rccm.200510-1666ST.

19. Zhang L, Zhu JY. Research progress of anti tuberculosis drug-induced liver injuries. Jiangxi Med J. 2019;54(9):1139-41. https://doi.org/10. 3969/j.issn.1006-2238.2019.9.049.

20. Zhang HJ, Shi ZX, Zhao LF, Gao TH, Li J. Analysis of clinical characteristics of 56 cases of liver injury caused by antitumor drugs. J Clin Hepatobiliary Dis. 2019;35:574-578. CNKI:SUN:LCGD.0.2019-03-105.

21. González J, Quiroga M, Escudero-Vilaplana V, Collado-Borrell R, HerranzAlonso A, Sáez MS. Posology adjustments of oral antineoplastic agents for special populations: patients with renal impairment, hepatic impairment and hematologic toxicities. Expert Opin Drug Saf. 2018;17:553-72. https://doi.org/10.1080/14740338.2018.1477937.

22. Xie ZZ, Liang Y, Sun LL. Evaluation of antitumor drug hepatotoxicity and dose adjustment in patients with impaired liver function. Chin J Clin Pharmacol. 2016;32:2203-5. https://doi.org/10.13699/..cnki.1001-6821. 2016.23.023.

23. Zhu SS, Chen X, Yan QY, Lin Z. Progress in clinical application of antitumor drugs. China Modern Doctor. 2019;57(9):164-8.

24. Han LN. Clinical study on integrated backscatter parameters in assessment of hepatic and renal toxicity by symphysicchemotheraphy (paclitaxel and cisplatin). Dalian: Dalian Medical University; 2008.

25. Yan X, Deng Y, Ma J, Li PJ, Yang ZJ, Yang XJ, Zhou Y. Research advance in mechanism of cisplatin toxic injury and its prevention and treatment by traditional chinese medicine. Chin J Exp Tradit Med Formulae. 2021;27(5):233-42. https://doi.org/10.13422/j.cnki.syfix.20202460.

26. Sun B, Li XY, Liu GL. Research progress on drug-induced liver injury related to non-steroidal anti-inflammatory drugs.World Chin J Digestion. 2015;23:3053-3059. CNKI:SUN:XXHB.0.2015-19-011.

27. Aithal GP, Ramsay L, Daly AK, Sonchit N, Leathart JBS, Alexander G, Kenna JG, Caldwell J, Day CP. Hepatic adducts, circulating antibodies, and cytokine polymorphisms in patients with diclofenac hepatotoxicity. Hepatology. 2010;39:1430-40. https://doi.org/10.1002/hep.20205.

28. Larson AM. Acetaminophen hepatotoxicity. Clin Liver Dis. 2003;7:35167. https://doi.org/10.1016/j.cld.2007.06.006.

29. Li HY, Yang CP, Jin HT. Recent research progress in mechanism of liver injury induced by common drugs. Chin J Pharmacovigilance. 2019;16:750-6. https://doi.org/10.19803/j.1672-8629.2019.12.09.

30. Seif A, Howida S. Physiological changes due to hepatotoxicity and the protective role of some medicinal plants. Beni-Suef Univ J Basic Appl Sci. 2016;5(2):134-46. https://doi.org/10.1016/j.bjbas.2016.03.004.

31. Divya S, William CC, Ghanshyam U. Drug-induced liver toxicity and prevention by herbal antioxidants: an overview. Front Physiol. 2016;6:363. https://doi.org/10.3389/fphys.2015.00363.

32. Jack A, Angela BR, Sandra SMC, Laura PJ. Acetaminophen-induced hepatotoxicity: role of metabolic activation, reactive oxygen/nitrogen species, and mitochondrial permeability transition. Drug Metab Rev. 2004;36(3-4):805-22. https://doi.org/10.1081/dmr-200033494.

33. Jennifer SA, Paul JP. Drug-induced liver injury from antiepileptic drugs. Clin Liver Dis. 2013;17:687-97. https://doi.org/10.1016/j.cld.2013.07.011.

34. Huang J, Ren N. Study progress of liver injury induced by antiepileptics. J Appl Clin Pediatr. 2007;22(6):465-7.

35. Michael PH, Cynthia J. Mech Drug Induced Liver injury. AAPSJ. 2006;8(1):E48-54. https://doi.org/10.1208/aapsj080106.

36. Karima B, Anissa I, Dominique P, Bernard F. Mitochondrial dysfunction in NASH: causes, consequences and possible means to prevent it. Mitochondrion. 2006;6(1):1-28. https://doi.org/10.1016/j.mito.2005.10 004.

37. Nie XL, Tao QM, Zhan SY, Wang D, Wu GZ, Cheng G. Systematic review of risk factors of oral ketoconazole hepatotoxicity. Chin J Pharmacovigilance. 2012;9:460-3. https://doi.org/10.3969/j.issn.1672-8629.2012.08. 004.

38. Rodriguez RJ, Acosta D. Metabolism of ketoconazole and deacetylated ketoconazole by rat hepatic microsomes and flavin-containing monooxygenases. Drug Metab Dispos. 1997;25:772-7. https://doi.org/ 10.1016/S1246-7391(99)80028-1.
39. Meng PP, Liu SK, He Y, Ma YT, Zuo SR, Song LY, Wang CJ. Analysis of clinical characteristics and influencing factors of 144 cases of drug-induced liver injury. Chin J Clin Pharmacol. 2017;33(467-469):473. https://doi. org/10.13699/j.cnki.1001-6821.2017.05.023.

40. Byeon JH, Kil JH, Ahn YC, Son CG. Systematic review of published data on herb induced liver injury. J Ethnopharmacol. 2019;233:190-6. https://doi.org/10.1016/j.jep.2019.01.006.

41. He S, Zhang C, Zhou P, Zhang XL, Ye TY, Wang RY, Sun GB, Sun XB. Herbinduced liver injury: phylogenetic relationship, structure-toxicity relationship, and herb-ingredient network analysis. Int J Mol. 2019;20:3633. https://doi.org/10.3390/ijms20153633.

42. Norman BH. Drug Induced Liver Injury (DILI). Mechanisms and medicinal chemistry avoidance/mitigation strategies. J Med Chem. 2020;63:11397-419. https://doi.org/10.1021/acs.jmedchem.0c00524.

43. Leise MD, Poterucha JJ, Talwalkar JA. Drug-induced liver injury. Mayo Clin Proc. 2014;89:95-106. https://doi.org/10.1016/j.mayocp.2013.09. 016.

44. Li F, Dong YZ, Zhang D, Zhang XM, Lin ZJ, Zhang B. Molecular mechanisms involved in drug-induced liver injury caused by urate-lowering Chinese herbs: a network pharmacology study and biology experiments. PLoS ONE. 2019;14(5): e0216948. https://doi.org/10.1371/journ al.pone.0216948.

45. Björnsson ES, Bergmann OM, Björnsson HK, Kvaran RB, Olafsson S. Incidence, presentation, and outcomes in patients with drug-induced liver injury in the general population of Iceland. Gastroenterology. 2013;144:1419-25. https://doi.org/10.1053/j.gastro.2013.02.006.

46. Chalasani N, Bonkovsky HL, Fontana R, Lee W, Stolz A, Talwalkar J, Reddy KR, Watkins PB, Navarro V, Barnhart H, Gu JZ, Serrano J. Features and outcomes of 899 patients with drug-induced liver injury: the DILIN prospective study. Gastroenterology. 2015;148:1340-52.e7. https://doi. org/10.1053/j.gastro.2015.03.006.

47. Bai ZF, Gao Y, Zuo XB, Wang JB, Xiao XH. Progress in research on the pathogenesis of immune regulation and idiosyncratic drug-induced liver injury. Acta Pharmaceutica Sinica. 2017;52(7):1019-26. https://doi. org/10.16438/1.0513-4870.2017-0315.

48. He LZ, Yin P, Meng YK, Tang JF, He TT, Niu M, Guo YM, Zhu Y, Jing J, Li CY, Ma ZJ, Wang JB, Bai ZF, Xiao XH. Immunological synergistic mechanisms of trans-/cis-stilbene glycosides in Heshouwurelated idiosyncratic liver injury. Sci Bull. 2017;62(11):748-51. https://doi.org/10.1016/j.scib.2017. 04.020

49. Wu BH, Zhan J, Chen MZ, Zhang L. Protective effects of COX-2 on chlorpromazine-induced liver injury in rats. Chin I Gastroenterol Hepatol. 2012;21:550-3. https://doi.org/10.3969/j.issn.1006-5709.2012.06.017.

50. Wang W, Bai MR, Jiang T, Li C, Li P, Zhou H, Wang ZM, Li LP, Jiang HD. Clozapine-induced reduction of I-carnitine reabsorption via inhibition/ down-regulation of renal carnitine/organic cation transporter 2 contributes to liver lipid metabolic disorder in mice. Toxicol Appl Pharmacol. 2019;363:47-56. https://doi.org/10.1016/j.taap.2018.11.007.

51. Zang WW, Zhu LP, Wu HS. Current status of antipsychotics and liver injury. J Neursci Mental Health. 2010;10:525-7. https://doi.org/10.3969/j. issn. 1009-6574.2010.05.030

52. Hassan F, Nikolina KC, Samir Z. Hepatoprotective properties of extensively studied medicinal plant active constituents: possible common mechanisms. Pharm Biol. 2015;53(6):781-91. https://doi.org/10.3109/ 13880209.2014.950387.

53. Ali N, Rashid S, Nafees S, Hasan SK, Sultana S. Beneficial effects of Chrysin against Methotrexate-induced hepatotoxicity via attenuation of oxidative stress and apoptosis. Mol Cell Biochem. 2014;385:215-23. https://doi.org/10.1007/s11010-013-1830-4.

54. Zhang S, Lu BA, Han X, Xu LN, Qi Y, Yin LH, Xu YW, Zhao YY, Liu KX, Peng $J$ Y. Protection of the flavonoid fraction from Rosa laevigata Michx fruit against carbon tetrachloride-induced acute liver injury in mice. Food Chem Toxicol. 2013;55:60-9. https://doi.org/10.1016/j.fct.2012.12.041.

55. Su XJ, Zhan J, Zhao J, Zhang Y. The protective effect of propolis flavonoids on immunological liver injury in mice. Int J Immunol. 2011;34:315-7. https://doi.org/10.3760/cma.j.issn.1673-4394.2011.04. 019.

56. Wang JD, Li P, Li YM. Research progress of therapeutic drugs for liver injury. Chin Hosp Pharm J. 2013;33:1528-30. https://doi.org/10.13286/j. cnki.chinhosppharmacyj.2013.18.020. 
57. Zhang HN, Zhou YF, Liu JB, Pang QH. Exploring protective effects and mechanisms of quercetin on liver injury based on both NF-kB and Nrf2 signaling pathways. Acta Agric Boreali Occidentalis Sinica. 2020;29(1):143-9. https://doi.org/10.7606/j.issn.1004-1389.2020.01.017.

58. Chen DL, Liu Y, Ji CF, Fu Q, Huang LY. Protective effect of quercetin on cisplatin-induced liver injury through NLRP inflammatory body related pathway. Chin J Mod Appl Pharm. 2021;38(17):2105-9. https://doi.org/ 10.13748/j.cnki.issn1007-7693.2021.17.009.

59. Xie WY, Jiang $Z H$, Wang J, Zhang XY, Matthias FMM. Protective effect of hyperoside against acetaminophen (APAP) induced liver injury through enhancement of APAP clearance. Chem Biol Interact. 2016;246:11-9. https://doi.org/10.1016/j.cbi.2016.01.004.

60. Wan JY, Kuang G, Zhang L, Jiang R, Chen YT, He Z, Ye DY. Hesperetin attenuated acetaminophen-induced hepatotoxicity by inhibiting hepatocyte necrosis and apoptosis, oxidative stress and inflammatory response via upregulation of heme oxygenase-1 expression. Int Immunopharmacol. 2020;83: 106435. https://doi.org/10.1016/j.intimp.2020. 106435.

61. Han WJ, Wu Q, Ding M, Zhang XH, Liu S, Chen Y, Duan ZP. Protective effect of naringin on drug-induced $\mathrm{HL}-7702$ cells by inhibiting CYP450 gene expression. Chin J Gastroenterol Hepatol. 2019;28(7):721-6. https://doi.org/10.3969/j.issn.1006-5709.2019.07.001.

62. Du YC, Zhang H, Zhong FR, Chen HL, Lai L, Qian B1, Peng T, Xia XM, Fu WG. Protective effect of pinocembrin in a mouse model of liver injury induced by acetaminophen. J Clin Hepatol. 2020;36(3):608-11. https:// doi.org/10.3969/j.issn.1001-5256.2020.03.027

63. Wei Z, Jia Q, Yun W, Zhang YH, Xia M. The anthocyanin cyanidin-3-O$\beta$-glucoside, a flavonoid, increases hepatic glutathione synthesis and protects hepatocytes against reactive oxygen species during hyperglycemia: involvement of a cAMP-PKA-dependent signaling pathway. Free Radic Biol Med. 2012;52:314-27. https://doi.org/10.1016/j.freeradbio med.2011.10.483.

64. Jiménez-Arellanes MA, Gutiérrez-Rebolledo GA, Meckes-Fischer M, León-Díaz R. Medical plant extracts and natural compounds with a hepatoprotective effect against damage caused by antitubercular drugs: a review. Asian Pac J Trop Med. 2016;9(12):1141-9. https://doi. org/10.1016/j.apjtm.2016.10.010.

65. Luo XY, Mai YS, Zhu L, Zhang XJ, Huang S, Lai XP. Protective effect and mechanism of total flavonoids of Fructus Livistonae on acetaminophen-induced liver injur. Chinese Tradit Herbal Drugs. 2019;50:92530. https://doi.org/10.7501/j.issn.0253-2670.2019.04.020.

66. Wang XX, An JH, Wang ZL. Protective effect of total flavonoids extracted from Polygonum perfoliatum L. on the liver injury caused by antituberculosis drugs in mice. Chin J Clin Pharmacol. 2021;37:713-7. https://doi.org/10.13699/j.cnki.1001-6821.2021.06.017.

67. Xi BT, Zhu ML, Gao Y, Zhang KF. Protective effect and mechanism of total flavonoids extracted from Polygonum perfoliatum $\mathrm{L}$. on liver injury induced by antituberculosis drug in mice. Pharmacol Clin Chin Materia Medica. 2017;33:51-51. https://doi.org/10.13412/j.cnki.zyyl.2017.05.014.

68. Truong VL, Ko SY, Jun M, Jeong WS. Quercitrin from Toona sinensis (Juss.) M.Roem attenuates acetaminophen-induced acute liver toxicity in HepG2 cells and mice through induction of antioxidant machinery and inhibition of inflammation. Nutrients. 2016;8:431. https://doi.org/10. 3390/nu8070431.

69. Xiong WC, Yuan ZX, Wang TS, Wu ST, Wu HZ. Quercitrin attenuates acetaminophen-induced acute liver injury by maintaining mitochondrial complex i activity. Front Pharmacol. 2021;12: 586010. https://doi. org/10.3389/fphar.2021.586010.

70. Fan XY, Lv HM, Wang LD, Deng XM, Ci XX. Isoorientin ameliorates APAP-induced hepatotoxicity via activation Nrf2 antioxidative pathway: the involvement of AMPK/Akt/GSK3 $\beta$. Front Pharmacol. 2018;9:1334. https://doi.org/10.3389/fphar.2018.01334.

71. Jiang ZT, Wang X, Wang JC, Chen XF, Wang JP, Pan JH. Effect of sedi herba total flavanones and isorhamnetin on APAP-induced injured L02 cells. Chin J Exp Tradit Med Formulae. 2018;24:121-5. https://doi.org/10. 13422/j.cnki.Syfjx.20180631.

72. Seo M, Kim H, Lee JH, Park JW. Pelargonidin ameliorates acetaminophen-induced hepatotoxicity in mice by inhibiting the ROS-induced inflammatory apoptotic response. Biochimie. 2020;168:10-6. https:// doi.org/10.1016/j.biochi.2019.10.009.
73. Liao CC, Day YL, Lee HC, Liou JT, Chou AH, Liu FC. ERK signaling pathway plays a key role in baicalin protection against acetaminopheninduced liver injury. Am J Chin Med. 2017;45:105-21. https://doi.org/10. 1142/S0192415X17500082.

74. Shi L, Hao ZX, Zhang SB, Wei MJ, Lu B, Wang ZT, Ji LL. Baicalein and baicalin alleviate acetaminophen-induced liver injury by activating Nrf2 antioxidative pathway: the involvement of ERK1/2 and PKC. Biochem Pharmacol. 2018;150:9-23. https://doi.org/10.1016/j.bcp.2018.01.026.

75. Yang GL, Zhang L, Ma L, Jiang R, Kuang G, Li K, Tie HT, Wang B, Chen XY, Xie TJ, Gong X, Wan JY. Glycyrrhetinic acid prevents acetaminopheninduced acute liver injury via the inhibition of CYP2E1 expression and HMGB1-TLR4 signal activation in mice. Int Immunopharmacol. 2017;50:186-93. https://doi.org/10.1016/j.intimp.2017.06.027.

76. Liu YT, Lu BN, Peng JY. Hepatoprotective activity of the total flavonoids from Rosa laevigata Michx fruit in mice treated by paracetamol. Food Chem. 2011;125:719-25. https://doi.org/10.1016/j.foodchem.2010.09. 080.

77. Du YC, Zhang H, Zhong FR, Chen HL, Lai L, Qian BL, Tan P, Xia XM, Fu WG. Protective effect of pinocembrin in a mouse model of liver injury induced by acetaminophen. J Clin Hepatol. 2020;36:608-11. https://doi. org/10.3969/j.issn.1001-5256.2020.03.027.

78. Papackova Z, Heczkova M, Dankova H, Sticova E, Lodererova A, Bartonova L, Poruba M, Cahova M. Silymarin prevents acetaminopheninduced hepatotoxicity in mice. PLOS ONE. 2018;13: e0191353. https:// doi.org/10.1371/journal.pone.0191353.

79. Bektur NE, Sahin E, Baycu C, Unver G. Protective effects of silymarin against acetaminophen-induced hepatotoxicity and nephrotoxicity in mice. Toxicol Ind Health. 2016;32:589-600. https://doi.org/10.1177/ 0748233713502841.

80. Ahmad MM, Rezk NA, Fawzy A, Sabry M. Protective effects of curcumin and silymarin against paracetamol induced hepatotoxicity in adult male albino rats. Gene. 2019;712: 143966. https://doi.org/10.1016/j. gene.2019.143966.

81. Xie WY, Jiang ZH, Wang J, Zhang XY, Melzig MF. Protective effect of hyperoside against acetaminophen (APAP) induced liver injury through enhancement of APAP clearance. Chem Biol Interact. 2016;246:11-9. https://doi.org/10.1016/j.cbi.2016.01.004.

82. Fu TH, Wang SJ, Liu JP, Cai EB, Li HJ, Li PY, Zhao Y. Protective effects of a-mangostin against acetaminophen-induced acute liver injury in mice. Eur J Pharmacol. 2018;827:173-80. https://doi.org/10.1016/j. ejphar.2018.03.002.

83. Lv HM, Xiao QF, Zhou JF, Feng HH, Liu GW, Ci XX. Licochalcone A upregulates Nrf2 antioxidant pathway and thereby alleviates acetaminophen-induced hepatotoxicity. Front Pharmacol. 2018;9:147. https:// doi.org/10.3389/fphar.2018.00147.

84. Zhang WX, Lan T, Dong JL, Guo J. Protective effects of kaempferol against acetaminophen in hepatocytes-induced injury. World Chin Med. 2019;4:39-43. https://doi.org/10.3969/j.issn.1673-7202.2019.01. 008.

85. Zhou LT, Song YQ, Zhao J, Qin HY, Zhang GQ, Zhou Y, Wu XA. Monoammonium glycyrrhizinate protects rifampicin-andisoniazid-induced hepatotoxicity via regulating the expression of transporter Mrp2, Ntcp, and Oatp1a4 in liver. Pharm Biol. 2016;54:931-7. https://doi.org/10. 3109/13880209.2015.1070878.

86. Sabina EP, Jerine PS, Prathap S, Geetha A. A comparison of hepatoprotective activity of Bacoside to Silymarin treatment against a combined Isoniazid and Rifampin-induced hepatotoxicity in female Wistar rats. J Histotechnol. 2019;42:128-36. https://doi.org/10.1080/01478885.2019. 1638535.

87. Yousef MI, Omar SAM, El-Guendi MI, Abdelmegid LA. Potential protective effects of quercetin and curcumin on paracetamol-induced histological changes, oxidative stress, impaired liver and kidney functions and haematotoxicity in rat. Food Chem Toxicol. 2010;48:3246-61. https://doi.org/10.1016/j.fct.2010.08.034.

88. Yan TT, Wang H, Zhao M, Yagai T, Chai YY, Krausz KW, Xie C, Cheng XF, Zhang J, Che Y, Li FY, Wu YZ, Brocker CN, Gonzalez FJ, Wang GJ, Hao HP. Glycyrrhizin protects against acetaminophen-induced acute liver injury via alleviating tumor necrosis factor a-mediated apoptosis. Drug Metab Dispos. 2016;44:720-31. https://doi.org/10.1124/dmd.116.069419. 
89. Deng QF, Zhou X, Chen HG. Advance in study on hepatoprotective effects and its mechanism of polysaccharides. China J Chin Materia Med. 2016;41:2958-67. https://doi.org/10.2147/DDDT.S68501.

90. Gao YQ, Liu YW, Shan JJ. Effects of natural polysaccharides on immune and alcholic liver injuries:research advances. J Int Pharm Res. 2017;44:1075-84. https://doi.org/10.2147/DDDT.S68501.

91. Gao YQ, Zhou ZH, Shan JJ. The effect of natural polysaccharides on drug-induced liver injury: research advances. J Int Pharm Res. 2019:46:163-70. https://doi.org/10.13220/j.cnki.jipr.2019.03.001.

92. Ye YN, Liu ES, Li Y, So HL, Cho CC, Sheng HP, Lee SS, Cho CH. Protective effect of polysaccharides-enriched fraction from Angelica sinensis on hepatic injury. Life Sci. 2001;69:637-46. https://doi.org/10.1016/s00243205(01)01153-5.

93. Wang J, Luo W, Li B, Lv JP, Ke XH, Ge DY, Dong RJ, Wang CG, Han Y, Zhang C, Yu HC, Liao Y. Sagittaria sagittifolia polysaccha-ride protects against isoniazid and rifampicin-induced hepatic injury via activation of nuclear factor E2-related factor 2 signaling in mice. J Ethnopharmacol. 2018:227:237-45. https://doi.org/10.1016/j.jep.2018.09.002.

94. Zhen XL, Li YG, Zhong S, Li ZZ, Ji DF. Protective effect of cordyceps militaris polysaccharide on hydrocortisone induced liver injury in mice. J Zhejiang Agric Sci. 2011. https://doi.org/10.16178/j.issn.0528-9017. 2011.03.070.

95. Fahmy SR, Amien Al, Abd-Elgleel FM, Elaskalany SM. Antihepatotoxic efficacy of Mangifera indica $\mathrm{L}$. polysaccharides against cyclophos-phamide in rats. Chem Biol Interact. 2016;244:113-20. https://doi.org/10.1016/j.cbi.2015.11.009.

96. Sener G, Ekşioğlu-Demiralp E, Cetiner M, Ercan F, Yeğen BC. Betaglucan ameliorates methotrexate- induced oxidative organ injury via its antioxidant and immunomodulatory effects. Eur J Pharmacol. 2006;542:170-8. https://doi.org/10.1016/j.ejphar.2006.02.056.

97. Li CY, Zhou YY, Wang FQ, Guo FL. Protection effect and antioxidation of polygonatum sibiricum polysaccharide on liver function in cisplatin-induced hepatotoxicity rats. Chin J Exp Tradit Med Formulae. 2013;19:229-31. https://doi.org/10.1016/j.ejphar.2006.02.056.

98. Karaduman D, Eren B, Keles ON. The protective effect of beta-1,3-Dglucan on Taxol-induced hepatotoxicity: a histopathologi-cal and stereological study. Drug Chem Toxicol. 2010;33:8-16. https://doi.org/ 10.3109/01480540903380472.

99. Lin GS, Luo DD, Liu JJ, Wu XL, Chen JF, Huang QH, Su LY, Zeng L, Wang HF, Su ZR. Hepatoprotective effect of polysaccharides isolated from against acetaminophen-induced liver injury in mice via regulation of the Nrf2-Keap1 signaling pathway. Oxid Med Cell Longev. 2018;69:2439. https://doi.org/10.1155/2018/6962439.

100. Zhao WH, Zeng C, Jia QQ, Yang XY. Effects of the Kunlun snow chrysanthemum polysaccharides on acetaminophen-induced oxidative stress, inflammation and apoptosis using animal model. Pak J Pharm Sci. 2018;31:985-90.

101. Wu K, Fa JL, Huang XY, Wu XM, Guo C. Hepatoprotective effects exerted by Poria Cocos polysaccharides against acetaminophen-induced liver injury in mice. Int J Biol Macromol. 2018;114:137-42. https://doi.org/10. 1016/j.jijbiomac.2018.03.107.

102. Hong SW, Lee HS, Jung KH, Lee H, Hong SS. Protective effect of fucoidan against acetaminophen-induced liver injury. Arch Pharm Res. 2012;35:1099-105. https://doi.org/10.1007/s12272-012-0618-5.

103. Che JY, Yang S, Qiao ZJ, Li H, Sun JH, Zhuang WY, Chen JG, Wang CM. Schisandra chinensis acidic polysaccharide partialy reverses acetaminophen-induced liver injury in mice. J Pharmacol Sci. 2019;140:248-54. https://doi.org/10.1016/j.jphs.2019.07.008.

104. Yang ZL, Wang HL, Xin Y, Li ZJ. Study on the mechanism of Aiye polysaccharide in preventing paracetamol liver poisoning. Lishizhen Med Materia Medica Res. 2012;23:2540-2. https://doi.org/10.3969/j.issn. 1008-0805.2012.10.068.

105. Ruan WF, Duan WM, Liang XM, Chen ZN, Huang RB. Protective effect of Yulangsan polysaccharide against hepatic injury in mice. Herald Med. 2015;34:406-8. https://doi.org/10.3870/yydb.2015.07.005.

106. Yuan L, Long TY, Chen HX, Liu XW, Huang RB, Jiao Y. Protective effect of Yulangsan polysaccharide on liver injury induced by cyclophosphamide in mice. China Pharmacist. 2014;17:1800-3. https://doi.org/10. 3969/j.issn.1008-049X.2014.11.003.

107. Dong Y, Huang J, Lin X, Zhang S, Jiao Y, Liang T, Chen Z, Huang R. Hepatoprotective effects of Yulangsan polysaccharide against isoniazid and rifampicin-induced liver injury in mice. J Ethnopharmacol. 2014;152:201-6. https://doi.org/10.1016/j.jep.2014.01.001.

108. Cai L, Zou S, Liang D, Luan L. Structural characterization, antioxidant and hepatoprotective activities of polysaccharides from Sophorae tonkinensis Radix. Carbohyd Polym. 2018;184:354-65. https://doi.org/ 10.1016/j.carbpol.2017.12.083.

109. Hong SW, Lee HS, Jung KH, Lee H, Hong SS. Protective effect of fucoidan against acetaminophen-induced liver injury. Arch Pharmacal Res. 2012;35:1099-105. https://doi.org/10.1007/s12272-012-0618-5.

110. Raghavendran HR, Srinivasan P. Effect of crude sulphated polysaccharide from brown algae against acetaminophen-induced toxicity in rats. Can J Physiol Pharmacol. 2008;86:660-6. https://doi.org/10.1139/ y08-072.

111. Lee JW, Byun EH, Sung NY, Raghavendran HR, Byun EB, Kim JH, Choi Jl, Shin MG, Byun MW. Effect of gamma irradiation on the efficacy of betaglucan against acetaminophen induced toxicity in mice. Chem Biol Interact. 2009;180:98-105. https://doi.org/10.1016/j.cbi.2008.11.018.

112. Wang J, Luo W, Li B, Lv J, Ke X, Ge D, Dong R, Wang C, Han Y, Zhang C, Yu $\mathrm{H}$, Liao Y. Sagittaria sagittifolia polysaccharide protects against isoniazidand rifampicin-induced hepatic injury via activation of nuclear factor E2-related factor 2 signaling in mice. J Ethnopharmacol. 2018;227:23745. https://doi.org/10.1016/j.jep.2018.09.002.

113. Gao Y, Zhong ML, Zhong JL, Zhang KF. Study of dicliptera chinensis polysaccharidein counteracting liver injury induced by antituberculosis drugs. J Guangzhou Univ Tradit Chin Med. 2014;31(953-956):1032. https://doi.org/10.13359/j.cnki.gzxbtcm.2014.06.023.

114. Fahmy SR, Amien Al, Abd-Elgleel FM, Elaskalany SM. Antihepatotoxic efficacy of Mangifera indica $L$. polysaccharides against cyclophosphamide in rats. Chemico Biol Interact. 2016;244:113-20. https://doi.org/10. 1016/j.cbi.2015.11.009.

115. Li E, Nie SP, Xie MY, Huang DF, Wang YT, Li C. Chemical composition and antioxidant activities in immumosuppressed mice of polysaccharides isolated from Mosla chinensis Maxim cv. jiangxiangru. Int Immunopharmacol. 2013;17:267-74. https://doi.org/10.1016/j.intimp.2013.05.033.

116. Cui JJ, Yuan JF, Zhang ZQ. Anti-oxidation activity of the crude polysaccharides isolated from Polygonum cillinerve (Nakai) Ohwi in immunosuppressed mice. J Ethnopharmacol. 2010;132:512-7. https://doi.org/ 10.1016/j.jep.2010.08.052.

117. Qian L, Liu Y, Li BX, Fu J, Li WY, Cao N, Tian YB, Xu DN. Polysaccharide of atractylodes macrocephala koidz may alleviates liver injury induced by cyclophosphamide via toll-like receptor 4 signaling pathway in goslings. J Ani Nutr. 2019;31:764-74. https://doi.org/10.3969/j.issn.1006267x.2019.02.033

118. Xin XM, Zhang QZ, Wang H, Feng L. The extraction of eucommia ulmoides oliv polysaccharides and its protective effect on liver of clophasphamidecy injured mice. Chin J Tradit Chin Med. 2007;25:1896-7. https://doi.org/10.13193/j.archtem.2007.09.137.xinxm.075.

119. Lin S, Hao G, Long M, Lai F, Li Q, Xiong Y, Tian Y, Lai D. Oyster (Ostrea plicatula Gmelin) polysaccharides intervention ameliorates cyclophosphamide-induced genotoxicity and hepatotoxicity in mice via the Nrf2-ARE pathway. Biomed Pharmacother. 2017;95:1067-71. https://doi. org/10.1016/j.biopha.2017.08.058.

120. Chen C, Liu X, Qi SS, Dias ACP, Yan JK, Zhang XY. Hepatoprotective effect of Phellinus linteus mycelia polysaccharide (PL-N1) against acetaminophen-induced liver injury in mouse. Int J Biol Macromol. 2020;154:1276-84. https://doi.org/10.1016/j.ijbiomac.2019.11.002.

121. Zheng XL, Li YG, Zhong S, Li ZZ, Ji DF. Protective effects of polysaccharides from silkworm Cordyceps militaris on liver damage induced by hydrocortisone in mice. Zhejiang Agric Sci. 2011;312:702-5. https://doi. org/10.16178/j.issn.0528-9017.2011.03.070.

122. Wang $Y C M$, Huang $K L$, Huang $L Y$, Hong $Y$, Zheng Y. Antioxidant and hepatoprotective effect of polysaccharides from synnemata of cordyceps cicadae against cyclophosphamide-induced liver injury in mice. Food Industry Sci Technol. 2019;40:45-50. https://doi.org/10. 13386/j.issn1002-0306.2019.24.008.

123. Wang J, LV JP, Ke XH, Li B, Yu HC, Han Y, Liao Y. Effects of sagittaria sagittifolin polysaccharide on CYP2E1 and CYP3A4 in INH/RFP-induced hepatotoxicity in HepG2 cells. Chin J Tradit Chin Med. 2018;36:2230-3. https://doi.org/10.13193/j.issn. 1673-7717.2018.09.046.

124. Qu H, Gao X, Wang ZY, Yi JJ. Comparative study on hepatoprotection of pine nut (Pinus koraiensis Sieb. et Zucc.) polysaccharide against different 
types of chemical-induced liver injury models in vivo. Int J Biol Macromol. 2020;155:1050-9. https://doi.org/10.1016/j.ijbiomac.2019.11.069.

125. Fang YX, Zhao J, Zhang GQ, Rao Z, Wu XA. Protective effects of seaweed polysaccharide on isoniazid and rifampicin induced liver injury rats. J Lanzhou Univ (Medical Edition). 2017;43:23-7. https://doi.org/10. 13885/j.issn. 1000-2812.2017.04.005.

126. Wang XX, Wang $X$, Zhang XH, Zou K, Liu CY, Yan Y, Wang YZ, Zhao SM. Protective effect of Seabucthorn Polysaccharide on acetaminopheninduced mice liver injury. Chin J Immunol. 2018;34:972-5. https://doi. org/10.3969/j.issn.1000-484X.2018.07.003.

127. Liu XF, Jiang SJ, Liang FH. Protective effect of astragalus polysaccharide on cyclophosphamide-induced toxicity in rats. J Guangzhou Med Univ. 2015;43:9-11. https://doi.org/10.3969/j.issn.2095-9664.2015.01.003.

128. Xu R, Liu Z, Fu Q, Duan H, Deng XK. Protective effects of polysaccharides from Panax japonicus on mice with liver injury induced by acetaminophen. J South Central Univ Natl (Natural Science Edition). 2020;39:51-5. https://doi.org/10.12130/znmdzk.20200110.

129. Lin G, Luo D, Liu J, Wu X, Chen J, Huang Q, Su L, Zeng L, Wang H, Su Z. Hepatoprotective effect of polysaccharides isolated from dendrobium officinale against acetaminophen-induced liver injury in mice via regulation of the Nrf2-keap1 signaling pathway. Oxid Med Cell Longev. 2018;2018:6962439. https://doi.org/10.1155/2018/6962439.

130. Zhong XH, Yang SY, Zhao LW, Zheng ZH, Zhang YZ, Wang S, Zhong Y, Guo M, Yang NJ. Protective effects of inonotus obliquus polysaccharide on liver injury induced by antituberculosis drugs in mice. Herald Med. 2014;33:558-61. https://doi.org/10.3870/yydb.2014.05.002.

131. Wu K, Fan J, Huang X, Wu X, Guo C. Hepatoprotective effects exerted by Poria Cocos polysaccharides against acetaminophen-induced liver injury in mice. Int J Biol Macromol. 2018;114:137-42. https://doi.org/10. 1016/j.ijbiomac.2018.03.107.

132. Che JY, Yang S, Qiao ZJ, Yang XH, Li H, Sun JH, Chen JG, Wang CM. Effect of Schisandra chinensis polysaccharide on apoptosis of hepatocytes induced by acetaminophen in mice. Food Ind Sci Technol. 2019;40(285-289):303. https://doi.org/10.13386/j.issn1002-0306.2019. 16.048 .

133. Diao JH, Liu J, Liu S, Liu N, Zhang YL, Yang SQ, Zhang SY. Experimental study on the protective effect of Pleurotus ostreatus polysaccharide on the liver of mice poisoned by cyclophosphamide. Lishizhen Med Materia Medica Res. 2011;22:2296-7. https://doi.org/10.3969/j.issn. 1008-0805.2011.09.116.

134. Shu GW, Qiu YH, Fu Q, Duan H, Yu HF, Deng XK. Alleviation effects of total polysaccharides from fruits of Morus alba $\mathrm{L}$. on acetaminopheninduced acute liver injury in mice. J South Central Univ Nationalities (Natural Science Edition). 2019;38:377-82. https://doi.org/10.12130/ znmdzk.20190311.

135. Tarsis, Zhang J, Hang YF, Han AP, Ding XS. Hepatoprotective activity of atractylodes chinensis (DC.) koidz water extract and polysaccharides against CCl4-induced acute liver injury in mice. Modern Chin Med Res Pract. 2011;25:45-47. https://doi.org/10.13728/j.1673-6427.2011.03.011.

136. Zhao Z, Wei QY, Hua WW, Liu YX, Liu X, Zhu YB. Hepatoprotective effects of berberine on acetaminophen-induced hepatotoxicity in mice. Biomed Pharmacother. 2018;103:1319-26. https://doi.org/10.1016/j. biopha.2018.04.175.

137. Park G, Kim KM, Choi S, Oh DS. Aconitum carmichaelii protects against acetaminophen-induced hepatotoxicity via B-cell lymphoma-2 proteinmediated inhibition of mitochondrial dysfunction. Environ Toxicol Pharmacol. 2016;42:218-25. https://doi.org/10.1016/j.etap.2016.01.012.

138. Bian XB, Wang SJ, Liu JP, Zhao Y, Li HJ, Zhang LX, Li PY. Hepatoprotective effect of chiisanoside against acetaminophen-induced acute liver injury in mice. Nat Prod Res. 2019;33:2704-7. https://doi.org/10.1080/14786 419.2018.1460841.

139. Wei XG, Wang HY, Huang XK, Sun XM, Liang YQ, Xu WP, Lin X, Lin J. Protective effect of alkaloid A from Acanthi llicifolii herba seu radix on drug-induced liver injury in mice. Chin J Exp Tradit Med Formulae. 2019;25:103-7. https://doi.org/10.13422/j.cnki.syfjx.20191503.

140. Morsy MA, Younis NS, El-Sheikh AAK, Turaif FHA, El-Daly M, Mohafez OM. Protective mechanisms of piperine against acetaminopheninduced hepatotoxicity may be mediated through TGFBRAP1. Eur Rev Med Pharmacol Sci. 2020;24:10169-80. https://doi.org/10.26355/ eurrev_202010_23237.
141. Zhan X, Zhang JQ, Chen H, Liu LY, Zhou YM, Zheng T, Li SX, Zhang YX, Zheng B, Gong Q. Capsaicin alleviates acetaminophen-induced acute liver injury in mice. Clin Immunol. 2020;220: 108578. https://doi.org/10. 1016/j.clim.2020.108578.

142. Ci R, Zhang K, Zhu A, Zang W. Dendrobine attenuates isoniazid- and rifampicin-induced liver injury by inhibiting miR-295-5p. Hum Exp Toxicol. 2020;39:1671-80. https://doi.org/10.1177/0960327120937047.

143. Shu GW, Qiu YH, Li W, Fu Q, Shen YJ, Deng XK. Protective effects of total alkaloids from lotus leaf on acetaminophen-induced acute liver injury in mice: roles of activating hepatic AMPK / Nrf2 signaling. Nat Prod Res. 2019;31(198-203):317. https://doi.org/10.16333/j.10016880.2019.2.003.

144. Han LT, Yao SQ, Cao S, Mo GY, Li JJ, Cao Y, Huang F. Triterpenoid saponins from anemone flaccida suppress tumor cell proliferation by regulating MAPK, PD1/PDL1, and STAT3 signaling pathways and altering cancer metabolism. Onco Targets Ther. 2019;12:10917-30. https://doi.org/10.2147/OTT.S212666.

145. Xu J, Wang S, Feng TH, Chen Y, Yang GZ. Hypoglycemic and hypolipidemic effects of total saponins from Stauntonia chinensis in diabetic db/db mice. J Cell Mol Med. 2018;22:6026-38. https://doi.org/10. $1111 / \mathrm{jcmm} .13876$.

146. Vinarova L, Vinarov Z, Atanasov V, Pantcheva I, Tcholakova S, Denkov $\mathrm{N}$, Stoyanov S. Lowering of cholesterol bioaccessibility and serum concentrations by saponins: in vitro and in vivo studies. Food Funct. 2015;6:501-12. https://doi.org/10.1039/c4fo00785a.

147. Qu XY, Gao H, Tao LN, Zhang YM, Zhai JH, Sun JM, Song YQ, Zhang SX. Astragaloside IV protects against cisplatin-induced liver and kidney injury via autophagy-mediated inhibition of NLRP3 in rats. J Toxicol Sci. 2019;44:167-75. https://doi.org/10.2131/jts.44.167.

148. Ma XD, Chi XQ, Yuan LJ, Wang YM, Li ZSY, Xu W, Rajput ZI, Hu SH. Immunomodulatory effect of ginseng stem-leaf saponins and selenium on Harderian gland in immunization of chickens to Newcastle disease vaccine. Vet Immunol Immunopathol. 2020;225: 110061. https://doi.org/10.1016/j.vetimm.2020.110061.

149. Kang SH, Kim TH, Shin KC, Ko YJ, Oh DK. Biotransformation of food-derived saponins, platycosides, into deglucosylated saponins including deglucosylated platycodin D and their anti-inflammatory activities. J Agric Food Chem. 2019;67:1470-7. https://doi.org/10. 1021/acs.jafc.8b06399.

150. Hu JN, Xu XY, Li W, Wang YM, Liu Y, Wang Z, Wang YP. Ginsenoside Rk1 ameliorates paracetamol-induced hepatotoxicity in mice through inhibition of inflammation, oxidative stress, nitrative stress and apoptosis. J Ginseng Res. 2019;43:10-9. https://doi.org/10.1016/j.jgr.2017. 07.003.

151. Ning CQ, Gao XG, Wang CY, Kong YL, Liu ZH, Sun HJ, Sun PY, Huo XK, Ma $X D$, Meng $Q$, Liu KX. Ginsenoside Rg1 protects against acetaminopheninduced liver injury via activating Nrf2 signaling pathway in vivo and in vitro. Regul Toxicol Pharmacol. 2018;98:58-68. https://doi.org/10. 1016/j.yrtph.2018.07.012.

152. Leng J, Wang Z, Fu CL, Zhang J, Ren S, Hu JN, Jiang S, Wang YP, Chen C, LiW. NF-KB and AMPK/PI3K/Akt signaling pathways are involved in the protective effects of Platycodon grandiflorum saponins against acetaminophen-induced acute hepatotoxicity in mice. Phytother Res. 2018;32:2235-46. https://doi.org/10.1002/ptr.6160.

153. Liu C, Zhang L, Zhu YH, Sun KC, He YL, Wang SK, Ding YM, Hu SS, He Y, Li L. Astragaloside IV ameliorates acetaminophen-induced liver damage by oxidative stress. J Anhui Sci Technol Univ. 2019;33:34-9. https://doi. org/10.19608/j.cnki.1673-8772.2017.0704.

154. Ghosh J, Das J, Manna P, Sil PC. Arjunolic acid, a triterpenoid saponin, prevents acetaminophen (APAP)-induced liver and hepatocyte injury via the inhibition of APAP bioactivation and JNK-mediated mitochondrial protection. Free Radical Biol Med. 2010;48:535-53. https://doi.org/ 10.1016/j.freeradbiomed.2009.11.023.

155. Ning C, Gao X, Wang C, Kong Y, Liu Z, Sun H, Sun P, Huo, Ma X, Meng Q, Liu K. Ginsenoside Rg1 protects against acetaminophen-induced liver injury via activating Nrf2 signaling pathway in vivo and in vitro. Regul Toxicol Pharmacol. 2018;98:58-68. https://doi.org/10.1016/j.yrtph.2018. 07.012 .

156. Leng J, Wang Z, Fu CL, Zhang J, Ren S, Hu JN, Jiang S, Wang YP, Chen C, LiW. NF-KB and AMPK/PI3K/Akt signaling pathways are involved in the protective effects of Platycodon grandiflorum saponins against 
acetaminophen-induced acute hepatotoxicity in mice. Phytotherapy Res. 2018:32:2235-46. https://doi.org/10.1002/ptr.6160.

157. Ma JQ, Yun Y, Hou WJ, Yang Y, Qian ZY. Protective effect of saponins of panax notoginseng on drug-induced liver injury in mice. Chin J Exp Formulas. 2013;19:246-9. https://doi.org/10.11653/syf2013230246.

158. Cao S, Lu BP, Hu DH. Effect of Total Saponins from tribulus terrestris on caspase - 3 expression of liver tissues in mice with acute liver injury induced by tripterygium glycosides. China J Chin Med. 2011;8:951-3. https://doi.org/10.16368/j.issn.1674-8999.2011.08.037.

159. Yan MH. Protective effect and mechanisms of Panaxadiol saponinsginsenoside and Rg5on acetaminophen-induced liver injury, Jilin Agricultural University, 2017.

160. Fan S, Liu C, Jiang Y, Gao Y, Chen YX, Fu KL, Yao XP, Huang M, Bi HC Lignans from Schisandra sphenanthera protect against lithocholic acid-induced cholestasis by pregnane $X$ receptor activation in mice. $J$ Ethnopharmacol. 2019;245: 112103. https://doi.org/10.1016/j.jep.2019. 112103.

161. Arulkumar N, Dae J, Ji-Hyun K, Hoyoung L, Myeong HJ. Gomisin N alleviates ethanol-induced liver injury through ameliorating lipid metabolism and oxidative stress. Int J Mol Sci. 2018;19:2601. https://doi.org/10. 3390/ijms19092601.

162. Chen YH, Lin FY, Liu PL, Huang YT, Chiu JH, Chang YC, Man KM, Hong CY, Ho YY, Lai MT. Antioxidative and hepatoprotective effects of magnolol on acetaminophen-induced liver damage in rats. Arch Pharmacal Res. 2009;32:221-8. https://doi.org/10.1007/s12272-009-1139-8.

163. Yan CX, Guo HM, Ding QQ, Shao YH, Kang D, Yu TJ, Li CJ, Huang HR, Du YS, Wang H, Hu KR, Xie L, Wang GJ, Liang Y. Multiomics profiling reveals protective function of schisandra lignans against acetaminopheninduced hepatotoxicity. Drug Metab Dispos. 2020;48:1092-103. https:// doi.org/10.1124/dmd.120.000083.

164. Jiang Y, Fan X, Wang Y, Chen P, Zeng H, Tan H, Gonzalez FJ, Huang M, Bi $\mathrm{H}$. Schisandrol B protects against acetaminophen-induced hepatotoxicity by inhibition of CYP-mediated bioactivation and regulation of liver regeneration. Toxicol Sci. 2015;143:107-15. https://doi.org/10.1093/ toxsci/kfu216.

165. Jiang Y, Fan X, Wang Y, Tan H, Chen P, Zeng H, Huang M, Bi H. Hepatoprotective effects of six schisandra lignans on acetaminophen-induced liver injury are partially associated with the inhibition of CYP-mediated bioactivation. Chem Biol Interact. 2015;231:83-9. https://doi.org/10. 1016/j.cbi.2015.02.022.

166. Li L, Zhang T, Zhou L, Zhou L, Xing G, Chen Y, Xin Y. Schisandrin B attenuates acetaminophen-induced hepatic injury through heat-shock protein 27 and 70 in mice. J Gastroenterol Hepatol. 2014;29:640-7. https://doi.org/10.1111/jgh.12425.

167. Liang L, Bi Q, Dong JC, Yang XX, Yu J. Progress on the development of natural medicines with hepatoprotective effects. Biotic Resour. 2018;40:148-58. https://doi.org/10.14188/j.ajsh.2018.02.009.

168. Uchida NS, Silva-Filho SE, Aguiar RP, Wirzler LAM, Cardia GFE, Cavalcante HAO, de Silva-Comar FMS, Becker TCA, Silva EL, Bersani-Amado CA, Cuman RKN. Protective effect of Cymbopogon citratus essential oil in experimental model of acetaminophen-induced liver injury. Am J Chin Med. 2017;45:1-18. https://doi.org/10.1 142/S0192415X17500318.

169. Zhang JY, Zhang SM, Bi JB, Gu JX, Deng Y, Liu C. Astaxanthin pretreatment attenuates acetaminophen-induced liver injury in mice. Int Immunopharmacol. 2017;45:26-33. https://doi.org/10.1016/j.intimp. 2017.01.028.

170. Yoshioka H, Aoyagi Y, Fukuishi N, Gui MY, Jin YR, Li XW, Adachi Y, Ohno N, Takeya K, Hitotsuyanagi Y, Miura N, Nonogaki T. Suppressive effect of kamebakaurin on acetaminophen-induced hepatotoxicity by inhibiting lipid peroxidation and inflammatory response in mice. Pharmacol Rep. 2017;69:903-18. https://doi.org/10.1016/.ppharep.2017.04.004.

171. Bai T, Yang Y, Wu YL, Jiang S, Lee JJ, Lian LH, Nan JX. Thymoquinone alleviates thioacetamide-induced hepatic fibrosis and inflammation by activating LKB1-AMPK signaling pathway in mice. Int Immunopharmacol. 2014;19:351-7. https://doi.org/10.1016/j.intimp.2014.02.006.

172. Gutiérrez-Rebolledo GA, Siordia-Reyes AG, Meckes-Fischer M, JiménezArellanes A. Hepatoprotective properties of oleanolic and ursolic acids in antitubercular drug-induced liver damage. Asian Pac J Trop Med. 2016;9:644-51. https://doi.org/10.1016/j.apjtm.2016.05.015.

173. Sabina EP, Peter SJ, Geetha A. A comparison of hepatoprotective activity of Bacoside to Silymarin treatment against a combined isoniazid and
Rifampin-induced hepatotoxicity in female Wistar rats. J Histotechnol. 2019:42:128-36. https://doi.org/10.1080/01478885.2019.1638535.

174. Wangkheirakpam SD, Joshi DD, Leishangthem GD, Biswas D, Deb L. Hepatoprotective effect of Auricularia delicata (Agaricomycetes) from India in rats: biochemical and histopathological studies and antimicrobial activity. Int J Med Mushrooms. 2018;20:213-25. https://doi.org/10. 1615/IntJMedMushrooms.2018025886.

175. Ibrahim SRM, El-Agamy DS, Abdallah HM, Ahmed N, Elkablawy MA, Mohamed GA. Protective activity of tovophyllin A, a xanthone isolated from Garcinia mangostana pericarps, against acetaminophen-induced liver damage: role of Nrf2 activation. Food Funct. 2018;9:3291-300. https://doi.org/10.1039/c8fo00378e.

176. Wu HT, Pang HY, Chen YP, Huang LS, Liu HX, Zheng YB, Sun CL, Zhang G, Wang GH. Anti-inflammatory effect of a polyphenol-enriched fraction from acalyphawilkesiana on lipopolysaccharide-stimulated RAW 2647 macrophages and acetaminophen-induced liver injury in mice. Oxid Med Cell Longev. 2018;68:21-38. https://doi.org/10.1155/2018/78580 94.

177. Zhang JP, Song QT, Han X, Zhang YY, Zhang Y, Zhang X, Chu X, Zhang $\mathrm{FH}$, Chu L. Multi-targeted protection of acetaminophen-induced hepatotoxicity in mice by tannic acid. Int Immunopharmacol. 2017;47:95105. https://doi.org/10.1016/j.intimp.2017.03.027.

178. Pang C, Sheng YC, Jiang P, Wei H, Ji LL. Chlorogenic acid prevents acetaminophen-induced liver injury: the involvement of CYP450 metabolic enzymes and some antioxidant signals. J Zhejiang Univ Sci B. 2015;16:602-10. https://doi.org/10.1631/jzus.B1400346.

179. Obogwu MB, Akindele AJ, Adeyemi OO. Hepatoprotective and in vivo antioxidant activities of the hydroethanolic leaf extract of Mucuna pruriens (Fabaceae) in antitubercular drugs and alcohol models. Chin J Nat Med. 2014;12:273-83. https://doi.org/10.1016/s1875-5364(14)60054-6.

180. Hussain T, Gupta RK, Sweety SK, Khan MS, Hussain MD, Arif MD, Hussain A, Faiyazuddin MD, Rao CV. Evaluation of antihepatotoxic potential of Solanum xanthocarpum fruit extract against antitubercular drugs induced hepatopathy in experimental rodents. Asian Pac J Trop Biomed. 2012;2:454-60. https://doi.org/10.1016/s2221-1691(12) 60075-6.

181. Zhou X, Cheung CM, Yang JM, Or PM, Lee WY, Yeung JH. Danshen (Salvia miltiorrhiza) water extract inhibits paracetamol-induced toxicity in primary rat hepatocytes via reducing CYP2E1 activity and oxidative stress. J Pharm Pharmacol. 2015;67:980-9. https://doi.org/10.1111/jphp. 12381.

182. Pari L, Kumar NA. Hepatoprotective activity of Moringa oleifera on antitubercular drug-induced liver damage in rats. J Med Food. 2002:5:171-7. https://doi.org/10.1089/10966200260398206.

183. Guo S, Zhang S, Liu L, Yang P, Dang X, Wei H, Hu N, Shi L, Zhang Y. Pinelliae rhizoma praeparatum involved in the regulation of bile acids metabolism in hepatic injury. Biol Pharm Bull. 2018;41:869-76. https:// doi.org/10.1248/bpb.b17-00972.

184. Qiu BX, Liu K, Zou L, Zhu HF, Feng S. Effects of Schisandrae chinensis fructus induced CYPs and Nrf2 activation on acute liver injury induced by acetaminophen. China J Chin Materia Med. 2018;4:4908-15. https:// doi.org/10.19540/j.cnki.cjcmm.20180625.006.

185. Yao LL, Zhang D, Liu JC, Zhu SY, Yang L, He JW. Phyllanthus emblica L. protected acetaminophen-induced hepatotoxicity via activating Nrf2/ARE signaling pathway. Modern Food Sci Technol. 2019;35:7-14. https://doi.org/10.13982/j.mfst.1673-9078.2019.3.002.

186. Hussain T, Subaiea GM, Firdous H. Hepatoprotective evaluation of trapa natans against drug-induced hepatotoxicity of antitubercular agents in rats. Pharmacogn Mag. 2018;14:180-5. https://doi.org/10.4103/pm.pm_ 237_17.

187. Wangkheirakpam SD, Joshi DD, Leishangthem GD, Biswas D, Deb L. Hepatoprotective effect of Auricularia delicata (Agaricomycetes) from, India in Rats: Biochemical and Histopathological Studies and Antimicrobial Activity. Int J Med Mushrooms. 2018;20:213-25. https://doi.org/10. 1615/IntJMedMushrooms.2018025886.

188. Zang SS, Liu YM, Liu F, Tian ZZ, Ma JT, Zhang GZ, Lyu HQ. Clinical effect of bicyclol in treatment of patients with liver injury induced by antituberculosis drugs. Med Pharm J Chin PLA. 2019;31(10):47-50. https:// doi.org/10.3969/j.issn.2095-140X.2019.10.011. 
189. Liu M. Preventive effect of Liuweiwuling tablet on liver injury induced by antitubercular agents. Chin J Liver Dis (Electronic Version). 2012:4(1):26-8.

190. Lei YC, LiW, Luo P. Liuweiwuling tablets attenuate acetaminopheninduced acute liver injury and promote liver regeneration in mice. World J Gastroenterol. 2015;21(26):8089-95. https://doi.org/10.3748/ wjg.v21.i26.8089.

191. He LZ, Meng YK, Zhang ZF, Han YZ, Wang Y, Wu SN, Sun XM, Xiao $X H$, Wang JB, Bai ZF. Protective effect of Liuwei Wuling tablets on idiosyncratic liver injury induced by Polygonum multiflorum in rats based on immunomodulation. Chin Tradit Herbal Drugs. 2017:48(1):136-42. https://doi.org/10.7501/j.issn.0253-2670.2017.01.019.

192. Zhang B, Jiang YN, Jiang L. Effects of Shuganning injection on liver injury caused by antituberculosis drugs. Chin Pharmacoecon. 2020;5:98-100. https://doi.org/10.12010/j.issn.1673-5846.2020.01.024.

193. Gao SJ. The clinical effect of sini shugan decoction in treating liver injury caused by drug-resistant tuberculosis. Guangming Tradit Chin Med. 2018;33:3694-6. https://doi.org/10.3969/j.issn.1003-8914.2018.24. 034.

194. Wang Y. The economic evaluation of the medicine for the treatment of liver injury by sunflower. Chin Pharmacoecon. 2018;13:79-81. https:// doi.org/10.12010/j.issn.1673-5846.2018.11.016.

195. Liu Y, Zhao B, Huang Y. Comparison of clinical effects of Jiangmeiling capsule and inosine tablet in the treatment of drug-induced liver injury caused by anti-tuberculosis fixed-dose combination preparation. J Aerospace Med. 2018;29(489-490):492. https://doi.org/10.3969/j.issn, 2095-1434.2018.04.054

196. Zheng N. The clinical effect of Shuganning injection in the treatment of anti-tuberculosis drug-induced liver injury. Chin Pharmacoecon. 2017;12:43-5. https://doi.org/10.12010/j.issn.1673-5846.2017.11.012

197. Lu ZY, Dang DJ, Wang J, Yang HL, Li J, Zhu XX, Diao SM, Zhang D, Zhang D, Guo LL. Effect observation of 196 cases of liver injury due to antituberculosis and fungal infection treated by baidan shugan formula. Shandong J Tradit Chin Med. 2017;36(647-649):653. https://doi.org/10. 16295/j.cnki.0257-358x.2017.08.007.

198. Zhuang MZ, Wang YP, Zheng X, Zhang ZY, Yuan RH, Zhu Y, Zhou F, Guo $Z W$. Clinical efficacy of Hugan Jiedu Decoction against drug induced liver injury and related inflammatory cytokines(HJD). Chin J Integr Trad West Med Dig. 2016;24:26-8. https://doi.org/10.3969/j.issn.1671-038X. 2016.01.07.

199. Hou LY. Study on the mechanism and effect of Yinlan Yigan granule in the treatment of acute drug-induced liver injury. Contemporary Med. 2013;19:152-3. https://doi.org/10.3969/j.issn.1009-4393.2013.34.118.

200. Gao SJ. Clinical analysis of Liuweiwuling therapy for patients with mild anti-tuberculosis drug-induced liver injury. J Integrated Tradit Chin Western Med Liver Dis. 2012;22(142-143):187.

201. Wei Y, Yao WX, Zhou X, Wang LY, Xie H, Zhao X. Clinical observation on effectiveness of Shuganning in treatment of patients with hepatic injury caused by chemotherapy drug. Chin J Hepatol (Electronic Edition). 2010;2:9-11. https://doi.org/10.3969/j.issn.1674-7380.2010.02.003.

202. LiYM. Efficacy of compound glycyrrhizin tablets and glucurolactone tablets in the treatment of transaminase elevation induced by antipsychotic drugs. Med Innovation China. 2019;16:149-52. https://doi.org/ 10.3969/j.issn.1674-4985.2019.28.039.

203. Gu J, Tang SJ, Tan SY, Wu Q, Zhang X, Liu CX, Gao XS, Yuan BD, Han LJ, Gao AP, Wu MY, Huang LH, Ma J, Xiao HP. An open-label, randomized and multi-center clinical trial to evaluate the effcacy of silibinin in preventing drug-induced liver injury. Int J Clin Exp Med. 2015;8:4320-7.

204. Luangchosiri C, Thakkinstian A, Chitphuk S, Stitchantrakul W, Petraksa S, Sobhonslidsuk A. A double-blinded randomized controlled trial of silymarin for the prevention of antituberculosis drug-induced liver injury. BMC Complement Altern Med. 2015;15:334. https://doi.org/10. 1186/s12906-015-0861-7.

205. Marjani M, Baghaei P, Dizaji MK, Bayani PG, Fahimi F, Tabarsi P, Velayati AA. Evaluation of hepatoprotective effect of silymarin among under treatment tuberculosis patients: a randomized clinical trial. Iran J Pharm Res. 2016;15:247-52.

206. Zhang S, Pan H, Peng X, Lu H, Fan H, Zheng XZ, Xu GS, Wang M, Wang JM. Preventive use of a hepatoprotectant against antituberculosis drug-induced liver injury: a randomized controlled trial. J Gastroenterol Hepatol. 2016;31:409-16. https://doi.org/10.1111/jgh.13070.
207. Heo E, Kim DK, Oh SH, Lee JK, Park JH, Chung HS. Effect of prophylactic use of silymarin on anti-tuberculosis drugs induced hepatotoxicity. Tuberc Respir Dis (Seoul). 2017;80:265-9. https://doi.org/10.4046/trd. 2017.80.3.265.

\section{Publisher's Note}

Springer Nature remains neutral with regard to jurisdictional claims in published maps and institutional affiliations.
Ready to submit your research? Choose BMC and benefit from:

- fast, convenient online submission

- thorough peer review by experienced researchers in your field

- rapid publication on acceptance

- support for research data, including large and complex data types

- gold Open Access which fosters wider collaboration and increased citations

- maximum visibility for your research: over $100 \mathrm{M}$ website views per year

At BMC, research is always in progress.

Learn more biomedcentral.com/submissions 